\title{
A PÁRKAPCSOLATTAL VALÓ ELÉGEDETTSÉG IDŐBELI ALAKULÁSA: LEHETSÉGES PÁLYÁK ÉS BEFOLYÁSOLÓ TÉNYEZÖK* Erát Dávid
}

\section{ÖSSZEFOGLALÓ}

Jelen tanulmány a magyar nők és férfiak párkapcsolattal való elégedettségének időbeli változását, valamint az arra potenciálisan befolyással bíró tényezők hatását vizsgálja. A kutatás csoportalapú pályaelemzést alkalmaz, az Életünk fordulópontjai panelkutatás 1-4. hullámának (2001/2002-2012/2013) felhasználásával. A pályaelemzés során a párkapcsolati minőség időbeli alakulásában mutatkozó, egymástól elkülönülő csoportok azonosithatók, rámutatva a nemek átlagos trendjei mögötti heterogenitásra. A párkapcsolattal való elégedettség tekintetében a nők esetében egy magas (57\%) és egy alacsony (43\%) pályával rendelkező csoport, míg a férfiak tekintetében szintén egy magas (54\%), valamint egy közepes (46\%) pálya azonosítható, ugyanakkor mind a négy csoportra jellemző az elégedettség kezdeti csökkenése.

A nők esetében az alacsony csoporthoz tartozást valószínüsitette a szülők válása, az élettársi kapcsolatban élés, a vitás konfliktuskezelési szokások, az anyagi nélkülözés gyakorisága és az egyedüli kenyérkeresői szerep, viszont csökkentette az élve született gyermekek száma, valamint a tradicionális vagy homogám relatív státuszhelyzet a kapcsolatban. A férfiak párkapcsolattal való

\footnotetext{
* Köszönet témavezetőmnek, Spéder Zsoltnak, valamint Berger Viktornak és Pirmajer Attilának értékes segítségükért és hozzászólásaikért. Továbbá köszönet illeti Daniel Nagint, a kutatásban alkalmazott eljárás megalkotóját, aki az elemzés koncepciójának véleményezésével, valamint a vizualizációs és adatstrukturálási kérdésekben nyújtott tanácsaival hozzájárult a tanulmány elkészüléséhez. A tanulmány azEFOP-3.6.3-VEKOP-16-2017-00007 azonosítószámú, „Tehetségből fiatal kutató. A kutatói életpályát támogatótevékenységek a felsőoktatásban” megnevezésü projektben, a Széchenyi 2020 program keretében, európai uniós (Európai Szociális Alap) társfinanszírozással valósult meg.
} 
elégedettségét a nőkkel egyező irányban határozta meg a szülők válása, a kapcsolat típusa, valamint a konfliktuskezelés módja, ugyanakkor az anyagi helyzethez és a státuszhoz kötődő változók egyike sem volt szignifikáns hatással.

Tárgyszavak: párkapcsolati minőség, elégedettség a párkapcsolattal, csoportalapú pályaelemzés, Életünk fordulópontjai

\section{Erát Dávid}

Pécsi Tudományegyetem, Bölcsészettudományi Kar, Társadalom- és Médiatudományi Intézet, Szociológia Tanszék

E-mail: erat.david@gmail.com

\section{BEVEZETÉS}

A párkapcsolatok vizsgálata a társadalomtudományok egyik klasszikus területének számít, kezdve a férfi-női kapcsolatot vizsgáló mikroszintű elemzésektől a makroszinten megmutatkozó demográfiai trendek értelmezéséig. A hazai kutatások az utóbbi évtizedekben több párkapcsolatspecifikus témával is foglalkoztak, például a szingliséggel és az egyszülős családok kérdésével (Rövid, 2018; Monostori, 2019), a különböző kapcsolattípusok terjedésével (Spéder, 2005) és az azokról kialakított véleményekkel (Rohr, 2017), a párkapcsolati instabilitás problémájával (Pilinszki, 2013) vagy a partnerkeresés folyamataival (Bukodi, 2004; Berger, 2019).

A hazai empirikus vizsgálatok látóterét azonban mind ez idáig elkerülte a párkapcsolati minőség, kiemelten annak időbeli változása átfogóbb elemzése. A téma kutatása kiemelten fontos, hiszen a párkapcsolat minőségének befolyása szerteágazó egyéni és össztársadalmi szinten is: többek között hatása van a gyermekvállalásra (Rijken and Thomson, 2011), összefügg az egyén egészségi állapotával (Robles et al., 2014 előre jelzi a válások bekövetkeztét (Birditt et al., 2012), valamint az egyéni jóllét egyik meghatározó eleme (Proulx et al., 2007).

Jelen tanulmány célja kettős. Egyfelől feltárni a párkapcsolattal való elégedettség időbeli változásait és az abban mutatkozó heterogenitást, másfelől felmérni a különböző háttértényezők, kapcsolatspecifikus jellemzők és társadalmi- 
gazdasági változók elégedettséget befolyásoló hatását. Az elemzések során továbbá fókuszba kerül a nők és férfiak összehasonlítása, feltételezve az eltérő folyamatok és hatások jelenlétét a két nem esetében. Fontos kiemelni, hogy bár a válás is összefügg egy kapcsolat minőségével, jelen esetben egy szelektívnek tekinthető, kapcsolatukat nem megszakító egyének csoportját elemzem.

A tanulmány első részében a párkapcsolati minőség mérésének módszerei és korlátait ismertetem, majd a főbb elméleti megközelítések és nemzetközi kutatási eredmények bemutatása következik. A második részben a különböző befolyásoló tényezők hatásának elméleti és empirikus alapjait fejtem ki, végül a csoportalapú pályaelemzéssel kialakított modell eredményeit tárgyalom, amelyhez az Életünk fordulópontjai panelkutatás adatait használtam fel.

\section{MÉRHETÖ-E EGY PÁRKAPCSOLAT MINŐSÉGE?}

A párkapcsolat minősége úgy definiálható, mint az egyén szubjektív értékelése párkapcsolatáról, különféle dimenziók mentén (Spanier, 1979). E dimenziók számáról és milyenségéről egységes meghatározás nincs, idetartozhat a boldogság, a harmónia, az alkalmazkodás, az elégedettség szubjektív megítélése, de a párkapcsolati ellentétek, problémák és az instabilitás jelenléte is (Gödri, 2001; Johnson et al., 1986). Bizonyos nézőpontok a szubjektív értékelés mellett tényleges viselkedési elemeket is a minőség fogalma alá sorolnak, mint például a kommunikáció, az egyetértés vagy az elköteleződés megnyilvánulási formái (Johnson, 1995).

Bár a párkapcsolat minősége többdimenziós, a legtöbb reprezentatív survey alapú vizsgálat átfogó skálát alkalmaz a fogalom megragadására. E skálák egyszerűen alkalmazhatók, és az eredmények összehasonlíthatóságát nagymértékben megkönnyítik, viszont a párkapcsolatok részletességét túlságosan leegyszerüsítik, megnehezítve a sajátosságok és diszfunkciók feltárását (Spanier, 1979). A komplexebb, több itemből álló mérőszámok alkalmasabbak a párkapcsolati minőség részletesebb mérésére, ugyanakkor ezeket ritkán alkalmazzák, különösen a hazai kutatásokban.

A mérési nehézségek másik oka a válaszok megbízhatóságában rejlik. A párkapcsolati minőséget tanulmányozók körében az 1960-as évek végén jelent meg a konvencionalizáció (conventionalization) kérdése, kiemelten Edmonds (1967) munkája mentén. A konvencionalizáció az egyén hajlamát jelenti arra, hogy kapcsolatát pozitív fényben tüntesse fel, ezzel megfelelve bizonyos társadalmi kívánalmaknak (Edmonds, 1967). A társadalom helyes- 
lésének ilyesfajta keresése jelentősen torzithatja a szubjektív véleményekre épülő eredményeket, ugyanakkor a jövőben lehetséges megoldást jelenthetnek e problémára a kérdezőbiztos nélküli vizsgálatok (Rohr, 2018).

A párkapcsolattal való elégedettség mint a minőség egyik dimenziója tehát mérhető, ugyanakkor egyetlen skála alkalmazásával alacsonyabb mértékủ komplexitás tárható fel. Az e tanulmányban bemutatott eredmények interpretálásakor továbbá figyelembe kell venni a lehetséges konvencionalizációs hatást is, ami a válaszok többnyire pozitív irányba történő eltolódását okozhatja.

\section{IDÖBELI VÁLTOZÁSOK}

A párkapcsolati minőséggel foglalkozó kutatások legfontosabb kérdése, hogy időben milyen változások figyelhetők meg annak alakulásában. Az elméletek meghatározó része kiemelten a párkapcsolat első éveire fókuszál, amely időszak után (különböző okokra visszavezethetően) csökkenő minőséget feltételez, míg a megközelítések másik csoportja a minőséget időben stabilnak vagy ideiglenesen változónak tekinti.

Az egyik legnépszerübb elméleti megközelítés a kiábrándulási modell (disillusionment model), mely szerint a pár tagjai az ismerkedés során egymás idealizált formájába szeretnek bele, és ezt az idealizációt a kapcsolat előrehaladtával egyre nehezebb fenntartani (Brehm et al., 2001). Ahogy az idő múlásával a pár tagjai megismerik egymást, azaz amikor a valóság találkozik a fantáziával, a párkapcsolat minősége csökken (Waller, 1938). A fiatal, idealizációkkal teli párkapcsolat így átalakul, és a kiábrándulás folyamata során potenciálisan a szeparáció felé halad (Huston et al., 2001a).

A kiábrándulási modellhez hasonló tendenciát feltételez a felmerülő nehézségek modell (emergent distress model) is. A kiábrándulási folyamattól eltérően a felmerülő nehézségek koncepciója szerint viszont nem az idealizáció megszűnése, hanem a párkapcsolat során felmerülő konfliktusok és problémák váltják ki a tartós minőségbeli csökkenést (Huston et al., 2001a; Huston et al., 2001b). A modell szerint a párok interperszonális képességei (kiemelten a konfliktuskezelés) meghatározzák a párkapcsolat minőségének alakulását. Ahogy a pár tagjai életük során egyre több problémával néznek szembe, a konfliktuskezelés esetleges hiányosságai miatt egymástól elzárkózhatnak, defenzívek, lenézők és kritikusak lehetnek, ami negativ hatást fejt ki a párkapcsolat minőségére (Gottman, 1993)!

' Ugyanitt Gottman e négy tulajdonságot az apokalipszis négy lovasának titulálta a párkapcsolatokra nézve. 
A csökkenést feltételező elméletek közül a harmadik az ún. nászút vége (honeymoon is over), más néven nászút utáni egyhangúság (honeymoon followed by blandness) hatást emeli ki. A nászút vége hatás hasonló a kiábrándulási modellhez, ugyanakkor a túlzóan pozitív kép a párkapcsolati életről alakul ki, nem pedig a partnerről. Míg a nászút időszaka alatt (a párkapcsolat első évei) intenzív érzelmi élet, egymással való törődés és optimizmus jellemzi a kapcsolatokat, idővel ezt felválthatja az apátia és az unalom, ami csökkenti a párkapcsolat minőségét - azaz a párkapcsolat szürke hétköznapjai elmaradnak a nászút időszakának boldogságától (Aron et al., 2002).

Az eddig felsorolt elméleti modellek a párkapcsolati minőség időbeli csökkenését hangsúlyozták, ugyanakkor több elképzelés ezzel ellentétes álláspontot képvisel. A tartós dinamika modell (enduring dynamics model) és az állandó problémák modell (perpetual problems model) feltételezi, hogy a párkapcsolatba lépő egyének már az udvarlás időszakában teljesen megismerik egymást, kialakítva párkapcsolatuk sajátos dinamikáját (Huston et al., 2001a; Huston and Houts, 1998). Mivel az ismerkedési fázisban a felek már felmérték párjukat, ezért a kiábrándulás, az időben megmutatkozó konfliktuskezelési hiányosságok vagy a nászút utáni egyhangúság hatása nem jelentkezik: a pár tagjai tudták, mire vállalkoznak, nem újdonság partnerük viselkedése az évek elteltével, és tisztában vannak párkapcsolatuk problémás részeivel. Ennek eredményeképp feltételezhető, hogy az ismerkedési fázis után fennmaradt kapcsolatok minősége stabil (nem feltétlenül magas szinten), időben nem mutat változást.

A csökkenő tendenciát feltételező elméletek másik alternatíváját képezi a hozzászokási modell (accomodation model). Ez hangsúlyozza, hogy bár bizonyos események és nehézségek befolyásolhatják a párkapcsolat működését, a pár idővel ezeken sikeresen felülkerekedhet, helyreállítva a párkapcsolat minőségét (Caughlin and Huston, 2006). A párkapcsolati minőség változékonyságát tehát egyfelől meghatározza a negatív események száma és a pár adaptációs képessége az új helyzetekhez.

A bemutatott főbb elméleti megközelítések többsége a párkapcsolat korai szakaszaira vonatkozott, illetve általánosságban fogalmazott meg különféle tendenciákat. A párkapcsolati minőség kutatásában kevés elméleti és empirikus munka foglalkozik a hosszabb, 30-40 évet meghaladó párkapcsolatokban uralkodó mechanizmusokkal. Bár a kutatók körében nincs konszenzus a pontos folyamatokról, általánosságban feltételezhető, hogy a párkapcsolati minőség az idősek körében magasabb. Rollins és Cannon (1974) szerint a párkapcsolat későbbi éveiben az egyénekre nehezedő szerepek száma és komplexitása csökken, ezzel egyidejüleg pedig a párnak több ideje és energiája van egymással 
foglalkozni, emelve a kapcsolat minőségét. Carstensen szerint társas érzelmi szelekciós hatás (socioemotional selectivity) érvényesül az idősebb párok esetében, amelynek hatására az idő előrehaladtával az egyének aktívan szűkítik a szociális környezetüket, és jobban fókuszálnak a közeli kapcsolataikra, potenciálisan javítva azok minőségét (Levenson et al., 1993).

\section{KORÁBBI EREDMÉNYEK}

A párkapcsolati minőség időbeli alakulásának tanulmányozása kiemelten az 1960-as években kezdődött meg, az azóta eltelt évtizedek során a kutatók keresztmetszeti, longitudinális, valamint retrospektív adatokra építve próbálták felmérni a lehetséges trendeket (áttekintésért lásd Hicks and Platt, 1970). A kutatások többsége a korábban ismertetett elméletek igazolását kereste, többnyire alacsony elemszámú, nem reprezentatív lekérdezésekből származó adatok felhasználásával.

Karney és Bradbury (1997) hatvan pár négy évre kiterjedő követésével vizsgálta a párkapcsolat minőségének alakulását. A vizsgálat eredményei szerint a válaszadók kétharmada kiemelkedően magasra értékelte párkapcsolatát, amit egy folyamatosan csökkenő trend követett, évente átlagosan 3-4\%-kal alacsonyabb minőségről beszámolva. Hasonló eredményekre jutottak Lindahl és munkatársai, valamint Kurdek is: a párok többsége a kapcsolat első 3-4 évében csökkenő párkapcsolati minőségről, majd a 8-9. évéig stagnálásról számolt be egyesek viszont folyamatosan csökkenő tendencia mellett a vizsgálat vége előtt felbontották kapcsolatukat (Lindahl et al., 1998; Kurdek, 1999). A folyamatosan romló tendenciára kifejezetten a rosszul kommunikáló, konfliktusaikat kevésbé jól kezelő párok voltak hajlamosak.

Niehuis és munkatársai (2015) a kiábrándulási modellt vizsgálva 144 pár érzelmi viselkedését elemezték a házasságot követő 26. hónapig. Igazolva a modell feltevéseit, a házasságkötést követő időszakban a férjek és feleségek pozitiv érzelmi megnyilvánulásai egyre ritkábbak lettek, ugyanakkor jelentős variabilitás mutatkozott páronként. Ha a pár tagjai a házasságkötési időszakban erőteljes érzelmi kapcsolatról, gyakori érzelemkifejezésről számoltak be, akkor a csökkenő tendencia markánsabb volt, mint azok körében, akik kisebb mértékủ érzelmességről nyilatkoztak.

A hosszabb ideje fennálló, idősek alkotta párkapcsolatok minőségének alakulásáról kevés empirikus tanulmány készült. VanLaningham és munkatársai 1980 és 1997 között kétezer fős mintán többnyire folyamatosan csökkenő, vagy 
csökkenés után stagnáló trendet mutattak ki (VanLaningham et al., 2001). Kevés bizonyíték szólt az idősek magasabb párkapcsolati minőségét feltételező elméletek mellett, mindössze két kohorsz (1961-1965 és 1971-1975) esetében találtak stagnálás utáni növekedő tendenciát. Vaillant és Vaillant tanulmánya retrospektív és nem retrospektív adatokat is felhasznált a párkapcsolatok negyven évének vizsgálatára, 109 férj és 74 feleség válaszai alapján (Vaillant and Vaillant, 1993). A retrospektív adatok ugyan kimutatták, hogy idősebb korban a párkapcsolati minőség nő, viszont sztenderd adatokon csökkenő tendenciát találtak. Az időskori párkapcsolati minőség javulása így mindössze a keresztmetszeti és retrospektív adatok sajátosságainak eredménye is lehet.

Az eddig ismertetett eredmények többsége tehát csökkenő vagy csökkenés után stagnáló trendet mutatott ki a párkapcsolati minőség alakulásában, igazolva az azt feltételező elméleti megközelítéseket. Bár egyes tanulmányok a férfiak és nők különválasztásán túl identifikáltak e trendtől eltérő csoportokat, a párkapcsolati minőség alakulásában mutatkozó heterogenitás kérdése az utóbbi évek kutatásaiban vált hangsúlyossá.

Anderson és munkatársai 1980 és 2000 között folytatott vizsgálatukban 706 házas egyént elemeztek (Anderson et al., 2010). A korábbi elemzésekben az átlagok szintjén domináló csökkenő tendencia csak a kapcsolatok 3,6\%-ára volt jellemző - a válaszadók kétharmada magasan stabil, ötödük alacsonyan stabil, míg tizedük U alakban változó párkapcsolati minőségről számolt be. Hasonló mértékű összetettséget találtak Birditt és munkatársai tizenhat évre kiterjedő elemzésükben (Birditt et al., 2012). A vizsgálatba bevont 320 házas személy esetében a nők többsége $U$ alakú közepes pályát, harmaduk enyhén csökkenő, negyedük magasan stabil, míg végül csak 7\%-uk erősen csökkenő tendenciát követett. A férjek ezzel szemben homogénebbnek mutatkoztak, mindössze három csoport különült el: egy közepes-stabil (61\%), egy magas-stabil (31\%), valamint kevesebb mint tizedük esetében U alakú mintázattal.

Alacsonyabb mértékű heterogenitást állapítottak meg 447 friss német szülő esetében Foran és munkatársai (2013). A kutatásban részt vevő férfiak és nők többsége stabilan magas minőségről számolt be, míg mindkét nem esetében csak a kapcsolatok tizede mutatott időben csökkenő tendenciát. Hasonlóan Lorber és munkatársai közel négyszáz párra kiterjedő elemzésükben megállapítják, hogy a nászút vége hatás korlátozódik a nők és férfiak egy szelektív csoportjára (Lorber et al., 2015).

Összességében a kutatási eredmények alapján ellentmondásos kép mutatkozik. Míg az átlagos tendenciákat vizsgáló, a heterogenitást kevésbé figyelembe vevő kutatási eredmények jellemzően csökkenést mutatnak a párkapcsolati 
minőség alakulásában, addig a kifejezetten eltérő csoportok identifikálását megcélzó kutatások többnyire stagnáló vagy stabil trendeket vázoltak fel, melyek mellett a csökkenő tendenciák a megkérdezettek alacsony számára voltak jellemzők. Az elméleti megközelítések sokszínüsége, valamint az empirikus eredmények alapján a kutatás elsődleges kérdései a következők:

1. Hány különféle párkapcsolati minőségpálya különböztethető meg a magyar nők és férfiak körében?

2. Milyen irányú trendek jellemzik az elkülönülő csoportok párkapcsolattal való elégedettségének alakulását?

\section{BEFOLYÁSOLÓ TÉNYEZÖK}

A párkapcsolati minőség időbeli változására nemcsak az idő múlása, hanem különböző háttértényezők, párkapcsolat-specifikus jellegzetességek, valamint társadalmi-gazdasági változók is hatással lehetnek. Jelen kutatás másodlagos kérdéseit e változók határozzák meg:

1. Mely tényezők befolyásolják a párkapcsolattal való elégedettség alakulását?

2. Különböznek-e a vizsgált tényezők hatásai a férfiak és a nők esetében?

\section{Háttértényezők}

Nem

Bernard munkái alapján elterjedt vélemény, hogy megkülönböztethető a férfi (his) és a nő (her) párkapcsolata (Bernard, 1972, idézi Corra et al., 2009; Bernard, 1976, idézi Shek, 1995). Ahogy korábban szó volt róla, a párkapcsolati minőség többdimenziós jelenség, azonban a férfiak és nők között eltérnek a különböző dimenziók súlyai. Egyfelől a férfiakhoz képest a nőknek más nemi szerepeknek kell megfelelniük, egyszerre betöltve a háziasszony, anya, jó feleség és kereső személy feladatait. Másfelől a nők sajátos elvárásokkal lépnek be a kapcsolatokba, a férfiaktól eltérően magasabb mértékủ intimitást és érzelmi közösséget elvárva. Bernard szerint eme eltérések miatt a nők nagyobb eséllyel számolnak be frusztrációról, elégedetlenségről és negativ érzésekről párkapcsolatuk vonatkozásában.

A korábban ismertetett heterogenitást vizsgáló kutatások közül kettő kimutathatóan eltérő csoportokról, trendekről számolt be a nők és férfiak esetén (Birditt et al., 2012; Lorber et al., 2015). Egyes kutatások igazolták, hogy a nők a 
párkapcsolat társas aspektusát a kapcsolattal való elégedettség mérlegelésekor előbbre veszik, mint a férfiak, valamint hogy a nők általánosan érzékenyebbek a kapcsolat működésével összefüggő problémákra, amelyeket tudatosabban fogalmaznak meg a válások előtt (Rhyne, 1981; Levinger, 1966; Cleek and Pearson, 1985). A nemek közötti különbség ugyanakkor metodológiai kérdés is lehet; egy nemrég publikált metaanalízis tanulságai szerint a diád alapú minták erős összefüggést mutatnak a férfiak és nők párkapcsolati minősége között, míg különbségek csak a klinikai vagy az egyéni megkérdezésen alapuló adatforrások alapján fedezhetők fel (Jackson et al., 2014). Bernard elméletére és a jelen tanulmányhoz hasonló módszereket alkalmazó kutatások eredményeire alapozva feltételezhető, hogy a nők és férfiak párkapcsolattal való elégedettsége eltérő időbeli alakulást mutat a magyar alminta esetén is.

\section{Szülők válása}

A párkapcsolat minőségét befolyásolja az egyén kommunikációs és problémamegoldó képessége, ugyanakkor e képességek részben a gyerekkori szocializációval és a szülők megfigyelésével alakulnak ki (Amato and DeBoer, 2001). Az elvált szülők gyerekeinek kevesebb idejük van e tudás elsajátítására, valamint nagyobb valószínüséggel tanulnak el nem megfelelő viselkedésmintákat, ami közvetetten a párkapcsolat minőségét csökkentheti. A hiányos vagy hibás képességátadás mellett Amato és DeBoer szerint maga a szétválás is fontos tényező: ezen keresztül a gyermekek megtapasztalják a kapcsolatok felbonthatóságát, így a jövőbeli kapcsolataik során kevésbé jövőorientált, a kapcsolat fennmaradásában kevésbé bízó attitűd alakulhat ki, továbbá mivel az egyén nem bízik a párkapcsolat tartósságában, így kevesebb energiát fektet bele, csökkentve annak minőségét.

A kérdést vizsgáló kutatások mindkét hatás mellett találtak bizonyítékot. A szülők rossz minőségű kapcsolata ténylegesen rontotta az egyén interperszonális képességeit a saját kapcsolatában, valamint az elvált szülők gyerekei nagyobb arányban gondolják, hogy kapcsolatuk válással végződik (Booth and Edwards, 1990; Amato, 1996). Whitton és munkatársainak eredményei szerint az elvált szülők leánygyermekei kevésbé hajlamosak bízni kapcsolatuk fennmaradásában, elköteleződni egy partner mellett, valamint kevésbé biztosak és elkötelezettek jelenlegi kapcsolatukban (Whitton et al., 2008). A rendelkezésre álló adatokban nem érhető el információ az egyén szüleinek párkapcsolati minőségéről, így a két uralkodó elméleti megközelítés direkt tesztelésére nincs lehetőség. Mindazonáltal mivel a két koncepció egyirányú hatást vázol fel, feltételezhető, hogy a szülők válásának negatív hatása van a párkapcsolati minőségre. 
Vallásosság

A párválasztás során a vallásosság bizonyos társadalmakban fontos szerepet játszik, és a párkapcsolat minőségét is befolyásoló tényező lehet (lásd Erát, 2018). A párkapcsolat belső dinamikáját meghatározza, ha az egyént a belsővé tett (intrinsic) vallásos magatartás jellemzi, azaz a különböző tanok és elvek mindennapi döntéseinek és másokhoz való viszonyának alapja (Allport and Ross, 1967). A megélt vallásosság következtében az egyén jobban figyel környezete igényeire, köztük párjáéra is, növelve a párkapcsolat minőségét (Dudley and Kosinski, 1990). A vallásosság továbbá segíthet a mindennapos kapcsolati nehézségek és kihívások leküzdésében, mérsékelve ezek negatív hatását (Sullivan, 2001).

Több empirikus kutatás rámutatott, hogy a vallásukat megélők párkapcsolati minősége jelentősen magasabb (Anthony, 1993; Dudley and Kosinski, 1990). Kiemelten fontos szerepe lehet a párkapcsolat magas minőségében a felek vallásos homogámiájának (Shehan et al., 1990). Bár a vallásosság, illetve a vallásos homogámia konzisztensen magasabb párkapcsolati minőséget eredményez, újabb kutatások rámutatnak e hatás gyengülésére (Myers, 2006). Az elméleti megközelítésekre és empirikus eredményekre alapozva a vallásosság esetében jelen kutatás hipotézise, hogy az aktív vallásgyakorlás pozitívan hat a párkapcsolati minőségre.

Válási tapasztalat

A jelenlegi párkapcsolatra a korábbi kapcsolati tapasztalatok által kifejtett hatást kiemelten a már elváltak esetében szokták tanulmányozni. A válási tapasztalatnak az elméletek negatív hatást tulajdonítanak a párkapcsolati minőségre nézve, szelekciós és intézményesülést előtérbe helyező érvelések mentén. Előbbi szerint az elvált személyek egy olyan szegmensét képezik a társadalomnak, amelynek a stabil, hosszú távon jól működő kapcsolat fenntartása problémát jelent (Glenn and Weaver, 1977). Utóbbi szerint az új kapcsolatban a volt férjekfeleségek, anyósok-apósok, mostohagyermekek is a szociális háló részei lesznek, viszont a velük való interakciót kevés norma szabályozza, így több a jelenlegi kapcsolatot érintő nézeteltérés és feszültség (Cherlin, 1978).

Vemer és munkatársai metaanalízisében 34 tanulmány alapján rámutattak, hogy a már elváltak párkapcsolatainak minősége valamivel alacsonyabb a válási tapasztattal nem rendelkezőkénél (Vemer et al., 1989). Más eredmények szerint az újraházasodott személyek párkapcsolatában a boldogság és az interakciók gyakorisága gyorsabban csökkent, mint az első házasok esetében, és e kapcsolatokra jellemzőbb volt a gyakori nézeteltérés (Booth and Edwards, 1992; Hobart, 1991). Különösen negatív hatása van a jelenlegi párkapcsolat minősé- 
gére, ha az egyén korábbi partneréhez továbbra is pozitívan kötődik (Buunk and Mutsaers, 1999). Összességében feltételezhető, hogy a nők és férfiak párkapcsolati minősége alacsonyabb, ha volt már korábbi válásuk.

\section{KAPCSOLATSPECIFIKUS SAJÁTOSSÁGOK}

\section{A kapcsolat típusa}

A párkapcsolat minőségében tapasztalható különbségek tekintetében az utóbbi évtizedben gyakori kutatási téma lett a párkapcsolati formák összehasonlítása, amit az élettársi kapcsolatok hazánkban is tapasztalható gyors terjedése hívott életre (Spéder, 2005). Egyes felfogások szerint az élettársi kapcsolatot választók egy sajátos, szelektív szegmensét képezik a társadalomnak, különösen a házasság által dominált társadalmakban (Liefbroer and Dourleijn, 2006; Bennett et al., 1988). A szelektivitás mellett e kapcsolatok a társadalomban még nem intézményesültek teljesen, így a házassághoz képest az elköteleződés alacsonyabb szintje és összetettebb interperszonális kapcsolatok jellemezhetik, csökkentve a kapcsolat minőségét (Nock, 1995).

A témát átfogóan kutató Brown eredményei szerint a kapcsolat első tíz évében a párkapcsolat minősége gyorsabban csökken a tartósan meg nem házasodók körében, viszont a házasok és a házasodni akarók hasonló minőségről számoltak be (Brown, 2003; 2004; et al. 2015), amit Skinner és munkatársai is megállapítottak korábban (Skinner et al., 2002). Ez alapján a kutatás hipotézise, hogy a tartósan élettársi kapcsolatot választók párkapcsolati minősége alacsonyabb, mint a házasoké.

\section{Konfliktuskezelés}

Az időbeli változásokat tárgyaló elméleti megközelítések közül több kifejezett hangsúlyt helyezett a pár konfliktuskezeléssel kapcsolatos képességeire. Egy a kooperációra és problémamegoldásra orientált pár a produktív együttműködéssel magasabb párkapcsolati minőséget érhet el, valamint a negatív életesemények befolyását is csökkenthetik (Wheeler et al., 2010). Ezzel szemben a konfliktusokat eszkaláló vagy egymást kerülő, destruktív jellegű problémakezelés a párkapcsolat minőségére káros hatást fejthet ki.

Az empirikus kutatások eredményei egyöntetủen igazolják a konfliktuskezelési mód befolyásoló erejét. A párkapcsolat első éveiben jellemző konfliktuskezelési forma meghatározza a párkapcsolat kezdeti minőségét és annak időbeli alakulását, valamint az együttmüködésre törekvő párok párkapcsolati minősége 
általában magasabb, mint a versengően viselkedőké (Li et al., 2017; Greeff and De Bruyne, 2000; Wheeler et al., 2010). Delatorre és Wagner 750 párra kiterjedő elemzésében szintén kimutatta, hogy a megértő konfliktuskezelési profillal rendelkező párok párkapcsolati minősége magasabb volt, mint az ellenséges vagy elkerülő pároké (Delatorre and Wagner, 2019). Az egybehangzó empirikus adatokat figyelembe véve várható, hogy a magyar férfiak és nők párkapcsolati minőségét is meghatározó tényezőnek mutatkozik a konfliktuskezelés módja.

\section{GYERMEKEK}

A párkapcsolat minőségére nézve többnyire negatív hatás tulajdonítható a gyermekek jelenlétének az uralkodó elméletek szerint. A korai felfogások alapján egy gyermek születése krízishelyzetet idéz elő a párkapcsolatban, melynek következtében a családi viszonyok átalakulnak, potenciálisan csökkentve a kapcsolat minőségét (Lemasters, 1957; Dyer, 1963). Továbbá a gyermekek egy kapcsolatban konfliktusforrásként is megjelenhetnek (White et al., 1986). A gyermekkel rendelkező párokkal szemben a gyermektelen kapcsolatokban viszont lehetőség (és több idő) adódhat az egymásra fókuszáló, kölcsönösen kielégítő párkapcsolati élet kiépitésére (Veevers, 1980).

A negatív hatás eltérő értelmezései szerint azonban a gyermekek egyszerủen a felbomlás felé haladó, rossz minőségủ kapcsolatokat hosszabb ideig összetartják, így nagyobb eséllyel kerülnek a kutatások látóterébe (Glenn and McLanahan, 1982). Végül egyes megközelítések szerint a gyermekvállalás egyenesen a párkapcsolat minőségének pozitív indikátora is lehet - az egyének olyan személlyel terveznek családot alapítani, akivel kapcsolatuk kielégítő, és számítanak annak hosszú távú fennmaradására (Becker et al., 1977; Cherlin, 1977).

A gyermekek jelenléte, mint a válást gátló tényező jól bizonyított a szakirodalomban (például Földházi, 2008; Liu, 2002), ugyanakkor a párkapcsolati minőségre kifejtett hatásuk kevésbé vizsgált. Egyes eredmények szerint a párkapcsolat minőségét és a pár tagjai közötti interakciót különböző társadalmi-gazdasági alpopulációkban is negatívan befolyásolja a gyermek jelenléte (White et al., 1986; Glenn and McLanahan, 1982). Ramu kutatásában a gyermekek hatása kiemelten a dolgozó nők esetében volt negatív, akiknek több szerepet kell egyszerre teljesíteniük (Ramu, 1984). Lupri és Frideres eredményei szerint az $U$ alakban változó párkapcsolati minőség mélypontjai a gyermekkel rendelkezők esetében hangsúlyosabbak, kiemelten a gyermek születése és a 
tinédzserkor vége közötti időszakban (Lupri and Frideres, 1981). Összességében a gyermekszám negatív hatása feltételezhető a párkapcsolat minőségének alakulására, ugyanakkor e hatás nem feltétlenül közvetlenül a gyermeknek tulajdonítható.

\section{TÁRSADALMI-GAZDASÁGI HELYZET}

\section{Anyagi helyzet}

A párkapcsolat fennállása során nemcsak belső, hanem különböző külső stresszorok is jelentkeznek, amelyek negatív irányba befolyásolhatják a kapcsolat minőségét. Az ilyen külső tényezők közül az egyik leggyakrabban kutatott a háztartás (objektív vagy szubjektív) anyagi helyzete (Bodenmann et al., 2007; Conger et al., 1994). A rossz anyagi helyzet a nélkülözés sajátos dinamikáján keresztül, valamint az igények kielégítetlensége miatt feszültségeket és konfliktusokat okozhat, rontva a párkapcsolat minőségét.

Az empirikus eredmények szerint a gazdasági nehézségek a párkapcsolat működésének legtöbb dimenziójára károsan hatnak, kiemelten az interakció minőségére (Hardie and Lucas, 2010; Aytac and Rankin, 2009; Conger et al., 1990). Bizonyos eredmények szerint a nők érzékenyebbek a rossz anyagi helyzet hatásaira: Kelley és munkatársai kutatásában az anyagi stressz a pár mindkét tagjának párkapcsolati minőségére negatív hatással volt, ugyanakkor a férfiak esetében a társsal történő megfelelő kommunikáció e hatást csökkentette, a nők esetében viszont nem (Kelley et al., 2018). Az eredmények alapján a kutatás hipotézise, hogy a nélkülöző anyagi helyzet negatívan befolyásolja a párkapcsolattal való elégedettség mértékét.

\section{Relativ viszonyok a kapcsolatban}

A kutatók a relatív helyzet és a kapcsolat felbomlásának esélye között gyakran vonnak párhuzamot, ugyanakkor a párkapcsolat minőségére is hatást gyakorolhat (bővebben Erát, 2019). Parsons szerint a családban az egyének szocializáció által meghatározott nemspecifikus szerepeket töltenek be, ami egymásrautaltságot és ezzel kohéziót teremt a kapcsolatban, elősegítve annak müködését és stabilitását (Parsons, 1940; 1942; 1943; 1953; 1955a; 1955b). Tradicionális szemszögből nézve így a férfiak a kenyérkereső, míg a nők a háztartással és a gyermekneveléssel kapcsolatos feladatokat látják el, legfeljebb minimális munkavégzés mellett. Parsons nézőpontjából a kapcsolat minőségét csökkenti és insta- 
bilitását növeli, ha a szerepek átfedésbe kerülnek vagy az uralkodó normáknak ellentmondanak, mert a pár tagjai között versengés és/vagy a szerepek miatti konfliktusok alakulhatnak ki.

Becker közgazdaságtani elméletében a párkapcsolatot egy javakat termelő egységnek tekintette, melynek hatékonyságát a felek bizonyos feladatokra való specializáltsága adja, szintén kölcsönös függést kialakitva (Becker, 1981). Csakúgy, mint Parsonsnál, a beckeri elméletben is negatívan hat a párkapcsolat működésére és az instabilitását növeli, ha a gazdasági szerepek átfedésbe kerülnek (csökkentve a specializáltságot és ezzel a kölcsönös függést), különösen, ha a nők társadalmi-gazdasági helyzete megközelíti vagy felülmúlja a férfiakét a kapcsolatban. Oppenheimer a Becker- és a Parsons-féle modelleket kritizálva megjegyzi, hogy e két gyakran alkalmazott modell az USA-ra érvényes, a kétkeresős családok máshol korán elterjedtek, és anyagilag előnyösebbek lehetnek a család számára, valamint hogy a konfliktus forrása nem feltétlenül a versengés, hanem a magas stressz a két munkahelyi kötelezettségből fakadóan (Oppenheimer, 1977).

Az egyenlő helyzetekre előnyösen tekintő alkudozási perspektíva (bargaining perspective) szerint a pár tagjai a társadalmi-gazdasági helyzetük által meghatározott alkupozíciókat foglalnak el a kapcsolatban, ami meghatározza a mindennapos döntéseket, valamint az erőforrások elosztását (Pollak, 2005). Egy egyenlőtlen alkudozási helyzet az egyén számára csökkentheti a párkapcsolat minőségét és növelheti a kapcsolat felbomlásának esélyét. Ehhez hasonlóan a homofiliaelmélet (homophily theory) szerint a státuszban és értékekben hasonló egyének jobban müködő párokat alkotnak a hasonló élethelyzetek és könnyebb kommunikáció miatt, így az emberek elsősorban a hozzájuk hasonlókat keresik párnak (Schaefer, 2012; Rogers and Bhowmik, 1970; Byrne and Nelson, 1965).

A relatív helyzetek szempontjából fontos a makrotársadalmi viszonyokat is figyelembe venni. Egy tradicionális társadalomban a párjuknál alacsonyabb helyzetű férfiak, illetve a női családfők a társadalom és a közeli szociális közegek felől negatív megítéléssel találkozhatnak (Safilios-Rothschild, 1975). Továbbá Fáber szerint a meghatározott nemi szerepekre épülő kapcsolatok háttérbe szorultak napjainkban, így az egyén feladatait és kötelezettségeit a kapcsolatban diskurzus határozza meg, ami növelheti a potenciális konfliktusokat a pár tagjai között (Fáber, 2019).

A pár tagjai relatív helyzetének hatását a párkapcsolat minőségére kevés empirikus tanulmány vizsgálta. Vannoy és Philliber, valamint Zhang eredményei szerint a nők alacsonyabb párkapcsolati minőségről számoltak be, ha státuszuk felülmúlja párjukét (Vannoy and Philliber, 1992; Zhang, 2015). Vannoy és Cubbins 
oroszországi mintán végzett kutatása szerint a párkapcsolatukkal leginkább a nem dolgozó nők elégedettek, valamint a kétkeresős párok esetén a kapcsolat minőségét mindkét fél számára csökkenti a nagy kereseti különbség (Vannoy and Cubbins, 2001).

A hasonló helyzetek pozitív hatását két tanulmány is hangsúlyozza. Pearlin eredményei szerint a homogám státuszú párok esetében tapasztalható a legkevesebb párkapcsolati probléma, Booth kutatásában pedig a dolgozó férjek magasabbra értékelték párkapcsolatuk minőségét, ha párjuk is dolgozott (Pearlin, 1975; Booth, 1977). Összességében bár ellentmondásosak az elméletek és az empirikus eredmények, feltételezhető, hogy a tradicionális relatív helyzetű párok esetében a párkapcsolati minőség magasabb, mint a homogám vagy magasabb női státusszal jellemezhető kapcsolatoké.

\section{ADATOK ÉS MÓDSZEREK}

\section{A kiválasztott alminta}

A kutatási kérdések vizsgálatához az Életünk fordulópontjai panelkutatás 1-4. hullámából rendelkezésre álló Iongitudinális adatbázist használtam fel (a kutatásról bővebben lásd Murinkó és Spéder, 2016). Az alminta főbb jellemzői az 1. táblázatban láthatók.

Az elemzés mintájába a panelvizsgálat időszaka alatt (2001/2002-2012/2013) ugyanazon partnerrel egy háztartásban élő házas és élettársi kapcsolatban lévő nők ( $n=1822$ fő) és férfiak ( $n=1446$ fő) kerültek be. Az elemzés látókörében tehát nem szerepelnek a panelkopás miatt kiesők², a külön élő partnerrel rendelkezők, valamint a vizsgálat ideje alatt kapcsolatukat felbontó vagy ideiglenesen/véglegesen szétköltöző személyek (bővebben: M1. táblázat). A párkapcsolatok átlagos hossza az első lekérdezés idején 21,49 év volt, a leghosszabb kapcsolat pedig már 53 éve fennállt. A kiválasztott alminta válaszadóinak többsége mind a négy hullámban nyilatkozott elégedettségéről párkapcsolatával (megfigyelési időpontok száma).

Az alminta kiválasztása során meg kell említeni a lehetséges szelekciós hatásokat. Látható, hogy az elemzéshez kiválasztott személyek kapcsolata egy 11-12 éves megfigyelési időszak alatt sosem szakadt meg, így feltételezhető, hogy a vizsgált kapcsolatok eleve magasabb minőségűek.

\footnotetext{
${ }^{2}$ Az Életünk fordulópontjai esetében tapasztalt panelkopásról bővebben: Bartus (2015) és Makay (2016).
} 
1. táblázat: Az Életünk fordulópontjai panelkutatás longitudinális adatbázisából kiválasztott alminta föbb jellemzői

\begin{tabular}{|c|c|c|c|}
\hline Jellemző & $n$ & \multicolumn{2}{|c|}{ Megoszlás } \\
\hline Teljes alminta & 3268 & - & \\
\hline Férfi & 1446 & $44,2 \%$ & \\
\hline Nő & 1822 & $55,8 \%$ & \\
\hline 1949-ig & 1104 & $33,8 \%$ & \\
\hline 1950-1959 & 947 & $29,0 \%$ & \\
\hline 1960-1969 & 672 & $20,6 \%$ & \\
\hline 1970-től & 545 & $16,7 \%$ & \\
\hline Volt válása korábban & 300 & $9,2 \%$ & \\
\hline Nem volt válása korábban & 2968 & $90,8 \%$ & \\
\hline Szülők elváltak/szétköltöztek & 293 & $9,0 \%$ & \\
\hline Szülők együtt maradtak & 2975 & $91,0 \%$ & \\
\hline Házas vagy házasságot kötött & 3130 & $95,8 \%$ & \\
\hline Élettársi kapcsolat & 135 & $4,1 \%$ & \\
\hline Mindig nyugodt konfliktuskezelés & 670 & $20,5 \%$ & \\
\hline Részben nyugodt konfliktuskezelés & 2307 & $70,6 \%$ & \\
\hline Sosem nyugodt konfliktuskezelés & 291 & $8,9 \%$ & \\
\hline Hipergám $(\mathrm{N}<\mathrm{F})$ & 807 & $24,7 \%$ & \\
\hline Homogám (N = F) & 1670 & $51,1 \%$ & \\
\hline Hipogám (N > F) & 791 & $24,2 \%$ & \\
\hline Jellemző & Átlag & Min. & Max. \\
\hline Párkapcsolat hossza (1. hullám) & 21,49 & 0 & 53 \\
\hline Megfigyelési időpontok (1-4. hullám) & 3,99 & 3 & 4 \\
\hline Elégedettség a párkapcsolattal (férfiak, 1. hullám) & 9,08 & 1 & 10 \\
\hline Elégedettség a párkapcsolattal (nők, 1. hullám) & 8,70 & 0 & 10 \\
\hline Gyerekszám (4. hullám) & 2,09 & 0 & 8 \\
\hline Nélkülöző időszakok (1-4. hullám) & 0,56 & 0 & 4 \\
\hline Egyedüli női kereső időszakok (1-4. hullám) & 0,40 & 0 & 4 \\
\hline
\end{tabular}

Forrás: Életünk fordulópontjai panelkutatás longitudinális adatbázisa (2001-2013). 


\section{A csoportalapú pályaelemzésröl}

A párkapcsolati minőség változásának feltárásához csoportalapú pályaelemzést (CSAP) használtunk (group-based trajectory modelling; Nagin 2005, 2014). A CSAP egy szemiparametrikus modellezési eljárás, amely homogén klasztereket képes azonosítani a különböző fejlődési irányok között. E modellezési forma a finite mixture modellek családjába tartozik, amely alkalmazható bináris, cenzorált skála, folytonos, valamint összegalapú változók esetében is. A hagyományos növekedési görbe modellek (growth curve modelling) feltételezik, hogy az egyének pályái egy átlagos trend körül helyezkednek el, ezzel szemben a CSAP megközelítés szerint az egyéni trendek heterogenitása egy véges számú, sajátos pályával rendelkező csoporttal jellemezhető. A megfelelő modellt a Nagin által felvázolt kétlépcsős eljárással választottuk ki: elsőként a megfelelő számú csoportot határoztuk meg (elsősorban a $\mathrm{BIC}$ és $\mathrm{AIC}^{4}$ mutatók segítségével), majd a csoportok pályájának pontos formáját definiáltuk.

A modell alkalmasságát a CSAP esetében három mutató határozza meg. Az átlagos posterior valószínűség (AvePP) megmutatja, hogy az egyének átlagosan mekkora valószínűséggel kerültek be egy adott csoportba, a helyes klasszifikáció esélye (OCC) a modell pontosságát méri a véletlenszerü besorolással szemben, végül a becsült arány (BA) és a tényleges arány (TA) összehasonlításával megvizsgálható, hogy a modell által becsült csoportméretekhez képest az egyének mekkora aránya került be ténylegesen egy adott csoportba. ${ }^{5}$

Mivel az egyének csoportbesorolása valószínűségalapú (azaz a legtöbb egyén bizonyos valószínűséggel tartozhat bármelyik csoportba), ezért az esetleges klasszifikációs hibák miatt a klasszikus csoportkülönbségeket összehasonlító eljárások nem alkalmazhatók. A CSAP során a lehetséges befolyásoló tényezőket a csoportok méretének és alakjának becslési eljárásába kell bevonni az időváltozó mellett, így a változóknak a különböző csoporttagságok valószínűségére kifejtett hatását lehet megbecsülni a klasszifikációs hibák el-kerülésével együttesen. A változók hatásait a megszokott két- vagy többváltozós logisztikus modellekkel megegyező módon kell értelmezni.

Összefoglalva: a modellezési eljárás során 1. a válaszadók 2001/2002 és 2012/2013 közötti párkapcsolattal való elégedettségét elemeztük, 2. a hasonló pályával rendelkező egyéneket homogén csoportokba soroltuk be az

\footnotetext{
${ }^{3}$ Az eljárás a STATA szoftverhez elérhető „traj” csomaggal készült, mely elérhető SAS felhasználók számára is, szintén „traj” néven. A csomagról bővebben lásd Jones and Nagin (2013).

${ }^{4}$ Bayesian Information criterion és akaike information criterion.

${ }^{5}$ A három mutató határértékét Nagin (2005) határozta meg. Az AvePP esetében ez minimum 0,7; az OCC esetében minimum 5; míg a BA és TA különbsége nem lehet jelentős.
} 
egyéni pályájuk formája alapján, és 3. bizonyos változóknak a csoporttagság valószínűségére való hatását vizsgáltuk.

Fontos megemlíteni az elemzés egyik fö limitációját: a válaszadók párkapcsolatának hossza a lekérdezés első évében nem azonos. A modellezési eljárásra e tényező nincs hatással (hiszen a mérések között eltelt idő egységes), ugyanakkor a bemutatott ábrákon az adott típusú pályával rendelkezők adott párkapcsolati évére vonatkozó átlagos párkapcsolati minőség látható, amelyen a modell által meghatározott görbe kapott helyet (hasonlóan egy keresztmetszeti elemzéshez). Ennélfogva bizonyos években a rendelkezésre álló adatok kevésbé megbízhatók - jellemzően az első hullámban az 5 évnél rövidebb és a 60 évnél hosszabb ideje fennálló kapcsolatok esetében igaz ez. A probléma részleges megoldásának érdekében a lekérdezések időszakában a 60. évet betöltött kapcsolatok párkapcsolati minőségére vonatkozó adatok nem szerepelnek a 60. év után, ezért 18 egyén esetében részleges adatokat használtunk fel az ábrákhoz.

\section{Mérőszámok}

Az elemzés függő változója a válaszadó párkapcsolattal való elégedettsége, amelyet 3-4 éves időközönként egy 0 és 10 közötti skálán értékeltek a megkérdezettek. ${ }^{6}$ A vizsgálat során alkalmazott időváltozó a párkapcsolat hossza, ami a kutatási kérdések szempontjából a legmegfelelőbbnek mutatkozott - alternatívaként az életkor, valamint az első lekérdezéstől számított évek is használhatók, melyek más-más kutatási kérdésekre adhatnak választ. Az időváltozó mellett a modellbe a kohorszhatások kontrollálása érdekében kohorszváltozók is bekerültek.

A magyarázóváltozók első csoportját a háttérváltozók alkotják, amelyeket dichotóm módon definiálunk: idetartozik a korábbi válási tapasztalat, a szülők válása, valamint a vallásosság. Mindhárom változó esetén az első hullámban közölt adatokat használtuk fel.

A változók második csoportja a kapcsolatspecifikus tényezőket takarja. A kapcsolat típusát tekintve két csoportot különböztetünk meg: a házasok és a vizsgálat ideje alatt házasságot kötőkét, valamint a végig élettársi kapcsolatban élőkét. A konfliktuskezelés változóban három kategóriát alakítottunk ki: azokét, akik a négy megkérdezés során mindig a nézeteltérések nyugodt kezeléséről, akik legalább egy alkalommal a nyugodtól eltérő, valamint akik

\footnotetext{
${ }^{6}$ A pontos kérdés: Kérem, a válaszlap segitségével mondja meg, mennyire elégedett a házasságával/élettársi kapcsolatával?
} 0-tól 10-ig értékeljen, ahol a 0 azt jelenti, hogy egyáltalán nem elégedett, a 10 pedig azt, hogy teljes mértékben elégedett! 
sosem nyugodt konfliktuskezelésről számoltak be a vitás helyzetek kapcsán. ${ }^{7}$ Végül a gyermekszám változó az utolsó lekérdezésig élveszületett gyermekek létszámát jelenti. A gyermekek hatásának pontosabb vizsgálatához a gyermek születésével azonos évben kellene információnak rendelkezésre állnia a párkapcsolati minőségről, azonban ez a jelen kutatásban a legtöbb megkérdezettnél nem volt elérhető.

A változók utolsó csoportját az anyagi helyzet és a relatív helyzet mutatói alkotják. A válaszadók mind a négy lekérdezés során jelezhették, hogy háztartásuk anyagi helyzetét hogyan látják; ezt felhasználva a nélkülözésnek tulajdonított negatív hatás vizsgálatához azokat a lekérdezéseket vontuk be (maximálisan négyet), amelyekben a válaszadó nélkülözőnek ítélte meg háztartása anyagi helyzetét. Ehhez hasonló módon a relatív helyzet vizsgálatához azok a lekérdezések kerültek a modellbe, ahol a nő volt a háztartás egyedüli kereső személye (de facto kenyérkeresőként funkcionálva), a pár tagjai végzettségének relatív viszonya mellett. A relatív viszonyok vizsgálatára a végzettség gyakran használt mutató (például Esteve et al., 2012; Grow and Van Bavel, 2015), előnye az időbeli stabilitása, valamint a válaszmegtagadások alacsony aránya, ugyanakkor belátható, hogy az egyén státuszának minden aspektusát nem jellemzi - még ha annak legtöbb elemével összefüggésben is van. ${ }^{8}$

\section{EREDMÉNYEK}

A kutatás első két kérdésének vizsgálatához először érdemes szemügyre venni a nők és férfiak átlagos elégedettségét párkapcsolatukkal (1. ábra). Mindkét nem esetében egy másodfokú görbe jellemezte legjobban a párkapcsolati minőség trendjeit (M2. és M3. táblázat).

A két nem párkapcsolati minősége klasszikus $U$ alakot követ, melyet a párkapcsolat korai éveiben csökkenés, míg a kései időszakban emelkedés jellemez. A párkapcsolattal való átlagos elégedettség a kezdeti években közel egyező (9,23 és 9,28 a 0. évben), ugyanakkor az ötödik év után a két trend láthatóan elválik, köszönhetően a nőknél tapasztalható meredekebb csökkenésnek.

\footnotetext{
${ }^{7}$ A3-4. hullám az 1-2. hullám nominális változóként kezelt kérdését ordinális skálaként mérte. Nyugodt konfliktuskezeléssel azok a válaszadók lettek jellemezve, akik gyakran vagy nagyon gyakran nyugodtan beszélik meg a nézeteltéréseiket, és nem jelezték, hogy a veszekedés, kiabálás és véleménymegtartás a ritkánál gyakrabban fordul elő, valamint nem említették a vitás helyzetek tettlegességig fajulását.

${ }^{8}$ A jövedelemre vonatkozó adatok használatával az alminta több mint fele, az összetettebb foglalkozási csoportok (Andorka-féle) alkalmazásával pedig az alminta közel harmada került volna ki az elemzés látóköréből.
} 
1. ábra: A férfiak és nők párkapcsolattal való átlagos elégedettsége a kapcsolat évei szerint

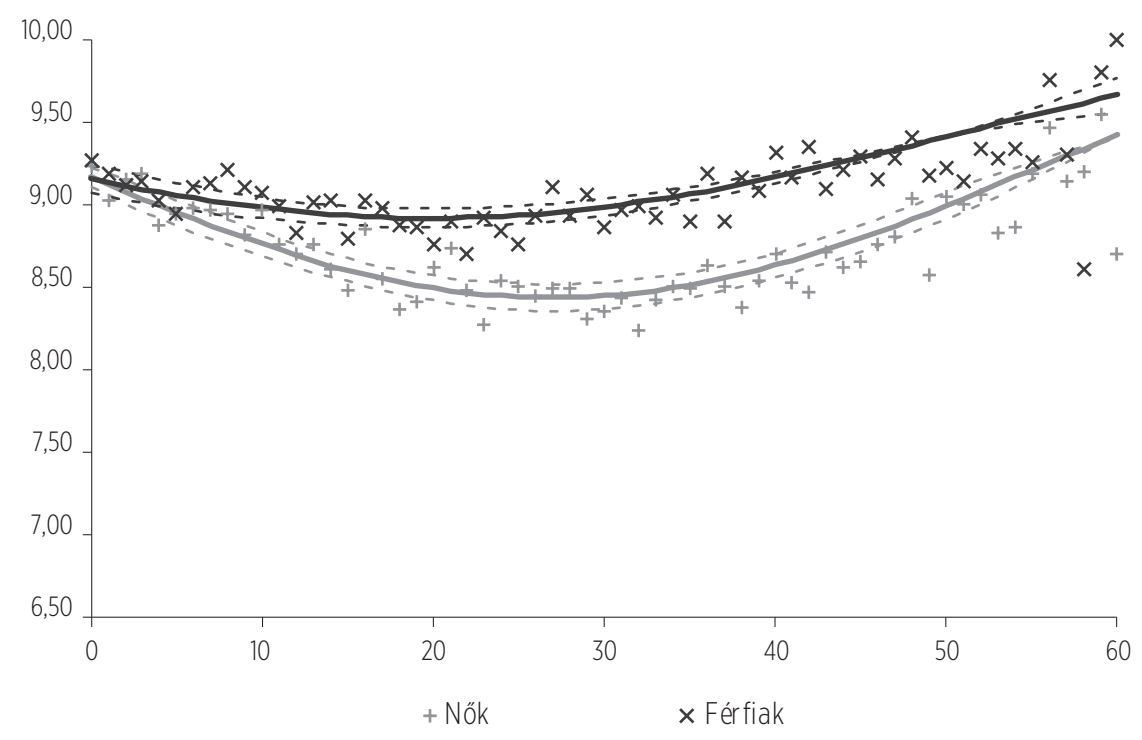

Forrás: Életünk fordulópontjai panelkutatás longitudinális adatbázisa (2001-2013), saját szerkesztés.

Összességében a férfiak és nők átlagos trendjei alapján megállapitható, hogy a párkapcsolati minőség a korai években csökken, majd az érettebb kapcsolatok esetén nő, valamint hogy a megkérdezett nők átlagosan kevésbé elégedettek a kapcsolatukkal. A kérdés, hogy eme átlagok mögött találhatók-e különböző, sajátos pályával rendelkező csoportok.

A 2. táblázatban láthatók a kétlépcsős eljárás eredményeképp legjobban illeszkedő modellek részletei (a lehetséges modellek illeszkedéséről bővebben: M2. és M3. táblázat). Mindkét nem esetében két-két sajátos pályával rendelkező csoport különíthető el a párkapcsolattal való elégedettség időbeli változása alapján. A megmutatkozó négy csoportra a párkapcsolat kezdeti éveiben átlagosan csökkenő, majd rövid stagnáló időszak után növekvő trend jellemző, ugyanakkor a csökkenések és növekedések mértéke eltérő (2. ábra).

A nőket tekintve a megkérdezettek 43\%-a alacsony, míg 57\%-a magas elégedettségi pályával volt jellemezhető. Az alacsony pálya esetében a nők párkapcsolattal való átlagos elégedettsége a kapcsolat 30-35. évéig gyorsan csökkent, a kapcsolat 0. évében látható átlagos 8,53-as értékről a 33. év 6,88-as mélypontjáig. A mélypontot követően a trend megfordul, átlagosan folyamatos növekedést mutatva a vizsgálat határát képező 60. évig. A magas pályával rendelkezők csoportja a párkapcsolatával a 0. évben kiemelkedően elégedett volt, 


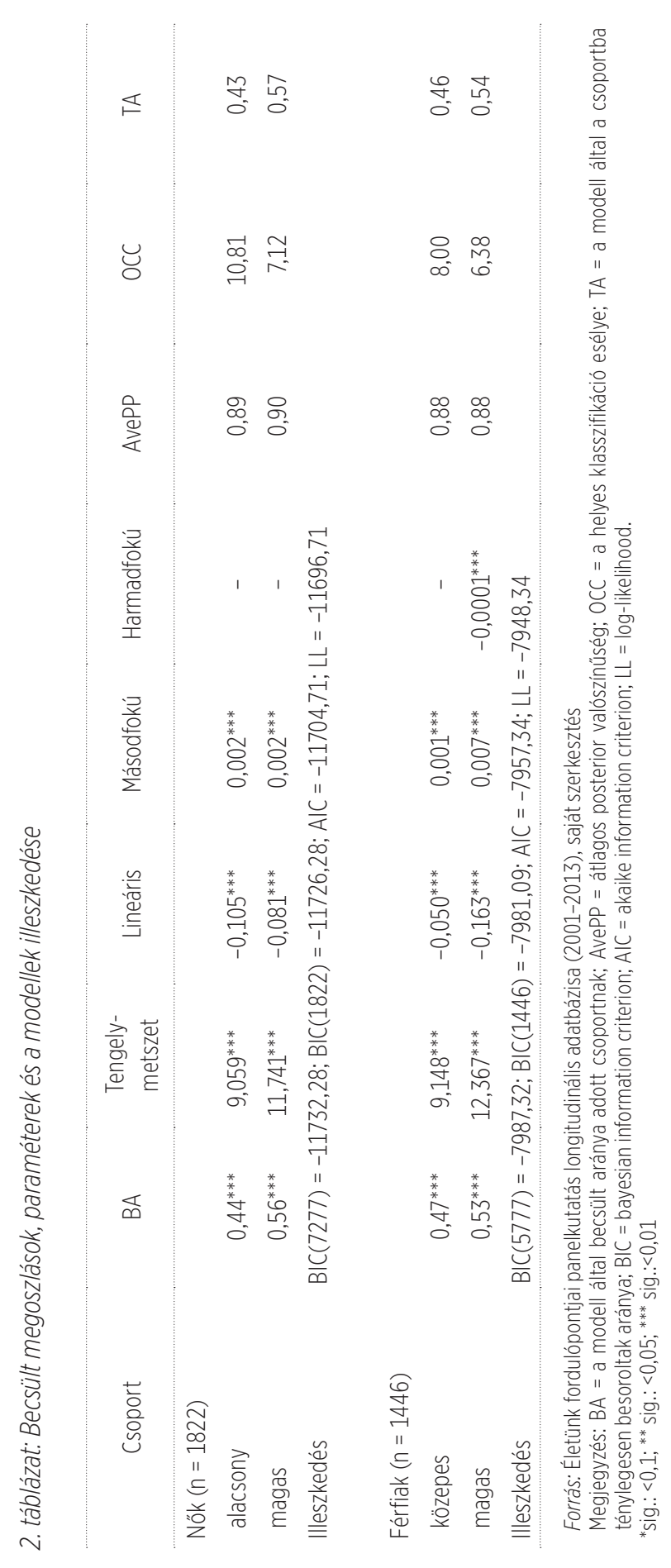


átlagosan 9,70-re értékelve elégedettségét. Ugyan esetükben is látszik csökkenés (szintén a 30. év körül mutatkozó 9,22-es mélyponttal) után bekövetkező emelkedés, a változások az alacsony pályájú csoportnál kevésbé markánsak.

\section{2. ábra: A csoportok párkapcsolattal való átlagos elégedettsége a kapcsolat évei szerint}

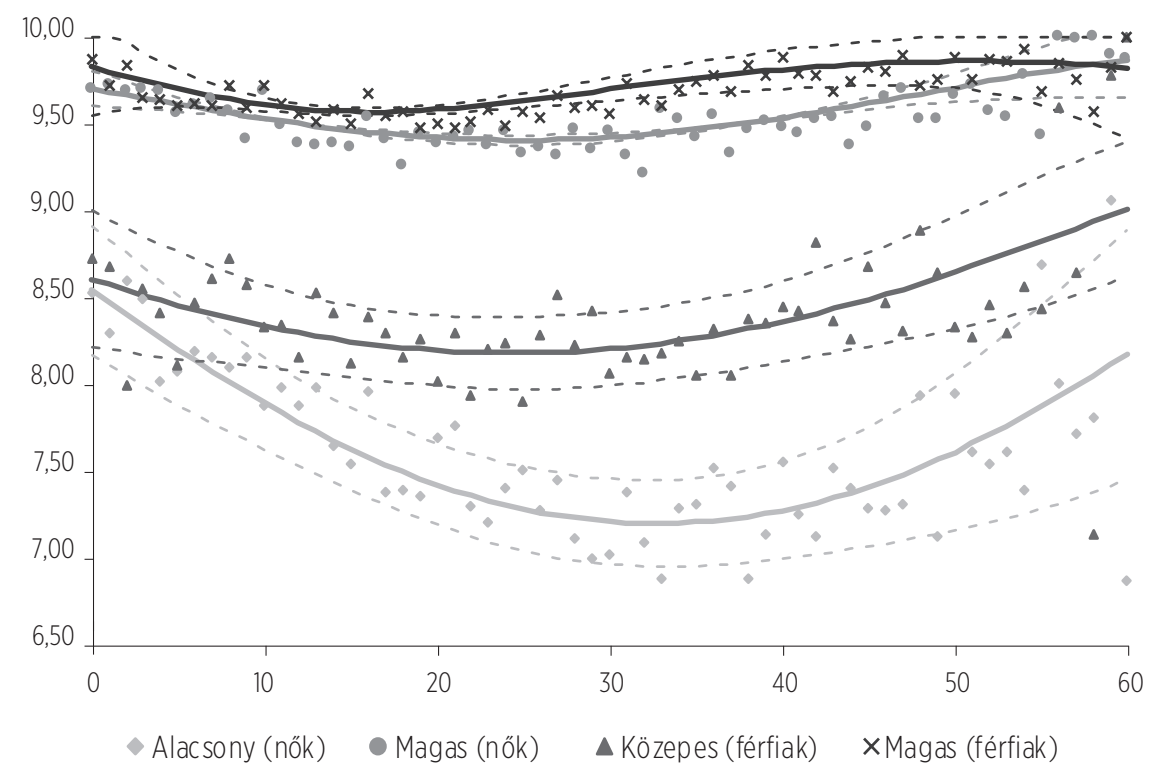

Forrás: Életünk fordulópontjai panelkutatás longitudinális adatbázisa (2001-2013), saját szerkesztés.

A férfiak esetében egy közepes, valamint egy magas pálya volt megfigyelhető, az előbbihez a férfiak 46\%-a, míg utóbbihoz 54\%-a tartozott. A közepes csoportba tartozók átlagos elégedettsége a kezdeti, relatíve közepes $(8,72)$ elégedettségi szintről csökkenve a 25-30. évi mélypont $(7,90)$ elérése után emelkedést mutat. A modellek által feltárt utolsó pályatípus a férfiak magas pályája. A férfi magas csoport a női magas csoportot felülmúlva átlagosan 9,88-ra értékelte elégedettségét kapcsolatával a 0. évben, amit a 19-20. évig tartó enyhe csökkenés után (9,48-as mélyponttal) növekedő tendencia vált fel. Bár e csoport elégedettségének alakulását a modell szerint egy harmadfokú görbe jellemzi legjobban, az 50. év után ismét csökkenést sugallva a párkapcsolat minőségében, mégis egy átlagosan stabilan magas elégedettségű csoportról beszélhetünk. 


\section{3. táblázat: A csoporttagság esélyét befolyásoló változók}

Nők (ref.: Magas)

Változók

\begin{tabular}{|c|c|c|c|c|c|c|}
\hline ValtozoK & $\operatorname{Exp}(B)$ & $\begin{array}{l}\text { Standard } \\
\text { hiba }\end{array}$ & T-érték & $\operatorname{Exp}(B)$ & $\begin{array}{l}\text { Standard } \\
\text { hiba }\end{array}$ & T-érték \\
\hline Konstans & $0,122^{* * *}$ & 0,339 & $-6,202$ & $0,150^{* * *}$ & 0,364 & $-5,214$ \\
\hline \multicolumn{7}{|l|}{ Kohorszok (ref.: 1949-ig) } \\
\hline $1950-1959$ & $1,471^{* *}$ & 0,193 & 1,996 & 1,353 & 0,189 & 1,601 \\
\hline 1960-1969 & $1,768^{* *}$ & 0,221 & 2,573 & $1,578^{*}$ & 0,239 & 1,911 \\
\hline 1970-től & 1,416 & 0,258 & 1,351 & 0,8 & 0,32 & $-0,698$ \\
\hline \multicolumn{7}{|l|}{ Háttértényezők } \\
\hline $\begin{array}{l}\text { korábbi válás (ref.: nem } \\
\text { volt válása) }\end{array}$ & 1,041 & 0,254 & 0,159 & 1,153 & 0,254 & 0,59 \\
\hline $\begin{array}{l}\text { szülök válása (ref.: nem } \\
\text { váltak el) }\end{array}$ & $1,646^{* *}$ & 0,234 & 2,128 & $1,895^{* *}$ & 0,277 & 2,311 \\
\hline $\begin{array}{l}\text { vallásosság (ref.: nem } \\
\text { vallásos) }\end{array}$ & 0,813 & 0,185 & $-1,113$ & 0,752 & 0,217 & $-1,316$ \\
\hline \multicolumn{7}{|l|}{$\begin{array}{l}\text { Kapcsolatspecifikus } \\
\text { sajátosságok }\end{array}$} \\
\hline $\begin{array}{l}\text { élettársi kapcsolat (ref.: } \\
\text { házas) }\end{array}$ & $3,209^{* * *}$ & 0,386 & 3,024 & $3,643^{* *}$ & 0,526 & 2,457 \\
\hline \multicolumn{7}{|l|}{$\begin{array}{l}\text { Konfliktuskezelés a } \\
\text { kapcsolatban (ref.: } \\
\text { mindig nyugodt) }\end{array}$} \\
\hline részben nyugodt & $7,437^{* * *}$ & 0,266 & 7,534 & $3,955^{* * *}$ & 0,236 & 5,834 \\
\hline sosem nyugodt & $69,051^{* * *}$ & 0,375 & 11,306 & $17,719^{* * *}$ & 0,412 & 6,971 \\
\hline gyerekszám & $0,837^{* *}$ & 0,075 & $-2,380$ & 0,987 & 0,081 & $-0,155$ \\
\hline \multicolumn{7}{|l|}{$\begin{array}{l}\text { Társadalmi-gazdasági } \\
\text { helyzet }\end{array}$} \\
\hline nélkülöző időszakok & $1,192^{* *}$ & 0,077 & 2,284 & 1,124 & 0,08 & 1,45 \\
\hline $\begin{array}{l}\text { egyedüli női kereső } \\
\text { időszakok }\end{array}$ & $1,192^{* *}$ & 0,081 & 2,159 & 1,103 & 1,062 & 1,062 \\
\hline \multicolumn{7}{|l|}{$\begin{array}{l}\text { Relatív végzettség (ref.: } \\
\text { hipogám }(\mathrm{N}>\mathrm{F}) \text { ) }\end{array}$} \\
\hline hipergám $(N<F)$ & $0,526^{* * *}$ & 0,193 & $-3,34$ & 1,217 & 0,216 & 0,91 \\
\hline homogám (N = F) & $0,675^{* *}$ & 0,166 & $-2,365$ & 1,153 & 0,186 & 0,763 \\
\hline Illeszkedés (Nők) & \multicolumn{6}{|c|}{$\mathrm{BIC}(7273)=-11629,31 ; \mathrm{BIC}(1821)=-11614,08 ; \mathrm{AIC}=-11553,50 ; \mathrm{LL}=-11531,50$} \\
\hline Illeszkedés (Férfiak) & \multicolumn{6}{|c|}{$\mathrm{BIC}(5765)=-7975,41 ; \mathrm{BIC}(1443)=-7959,48 ; \mathrm{AIC}=-7898,83 ; \mathrm{LL}=-7875,83$} \\
\hline
\end{tabular}

Forrás: Életünk fordulópontjai panelkutatás longitudinális adatbázisa (2001-2013) Megjegyzés: BIC = bayesian information criterion; $A \mathrm{IC}=$ akaike information criterion; $\mathrm{LL}$ = log-likelihood. $\mathrm{A}$ nőknél egy, a férfiaknál pedig három megfigyelés kikerült az elemzésből, a párkapcsolat típusáról esetükben nem volt elérhető információ *sig.: $<0,1$; ${ }^{* *}$ sig.: $<0,05 ;{ }^{* * *}$ sig.: $<0,01$ 
Összességében tehát a vizsgált almintában mindkét nem esetében elkülönül egy alig változó, átlagosan magas elégedettséggel jellemezhető csoport, illetve egy relatíve alacsonyabb elégedettségű, időben nagyobb változékonyságot mutató pályacsoport. A kutatás következő kérdése, hogy mely tényezők növelik az egyes csoportokba való tartozás esélyét. Az elemzésbe bevont változók hatásai a 3. táblázatban láthatók, a nők és férfiak esetén is referenciacsoportként a magas csoportokat használva?

A két nem összehasonlításában látható, hogy bizonyos háttér- és kapcsolatspecifikus változók kivételével a nők párkapcsolattal való elégedettségére a férfiakhoz képest több tényező hat. Nevezetesen a gazdasági helyzethez és státuszhoz köthető különböző mutatók a férfiakkal ellentétben a nők párkapcsolati minőségét befolyásolják. Továbbá a konvencionális szignifikanciaszint mellett csak a nőknél volt megfigyelhető kohorszhatás.

A háttérváltozókat nézve a nők és férfiak esetében is szignifikáns hatása volt a szülők válásának: ha az egyén szülei elváltak, várhatóan nagyobb (a nők 64\%-kal, míg a férfiak 89\%-kal nagyobb) eséllyel tartozott az alacsonyabb elégedettségü csoportokhoz. Ezzel szemben sem a korábbi válási tapasztalat, sem pedig a vallásoság nem bizonyult kimutatható befolyással rendelkező változónak.

Szintén egyező irányú, szignifikáns hatást fejtett ki a kapcsolatspecifikus változók közül a párkapcsolat típusa, illetve a konfliktuskezelés jellege. A vizsgálat idejéig élettársi kapcsolatban élő nők 3,2-szer, míg a férfiak 3,6-szer nagyobb eséllyel tartoztak az alacsonyabb minőségú csoportokba, mint a házasok vagy a vizsgált időszak alatt megházasodott egyének. Továbbá mindkét nem esetében a nézeteltéréseiket nyugodtan kezelő párok tagjaihoz képest a részben, illetve sosem nyugodt konfliktuskezelő kapcsolatok tagjai jóval nagyobb eséllyel tartoztak az alacsonyabb elégedettségú pályacsoportokhoz. Az élveszületett gyermekek száma csak a nők esetében volt kimutatható hatással, a várakozásoktól eltérően minden élveszületett gyermek körülbelül 16\%-kal csökkentette az alacsony csoportba való tartozás esélyét.

Végül az anyagi, illetve a kapcsolaton belüli relatív helyzetet vizsgáló változók szintén csak a nők esetében bizonyultak szignifikáns befolyásoló tényezőknek. Az anyagi helyzetet illetően minél több alkalommal jelezte egy női válaszadó a négy lekérdezés során, hogy nélkülöznek, annál nagyobb (időszakonként körülbelül 20\%-kal nagyobb) eséllyel tartozott az alacsony minőségű párkapcsolati pályacsoporthoz. Az anyagi helyzethez hasonlóan a négy lekérdezés során az

9 Mivel a szignifikanciaértékekben és a hatások erősségében nem mutatkozott jelentős változékonyság, ezért a végső, összes változót tartalmazó modellt ismertetem. A lépésenkénti eredmények a szerzőnél elérhetők. 
egyedüli női keresővel jellemezhető időszakok számával emelkedett az alacsony elégedettségű csoporthoz tartozás esélye. Ezzel egybehangzóan a relatív végzettség tekintetében látható, hogy a párjuknál magasabb végzettségű nőkhöz képest az alacsonyabb, illetve legfeljebb azonos végzettségű nők kisebb eséllyel tartoztak az alacsony párkapcsolati minőségü pályacsoportba.

\section{KÖVETKEZTETÉSEK}

Jelen tanulmány célja a párkapcsolattal való elégedettség időbeli változásának és meghatározó tényezőinek vizsgálata volt csoportalapú pályaelemzés alkalmazásával. Az elméleti áttekintésből látható volt, hogy a párkapcsolat minőségének mérése összetett feladat, amelyet az elérhető mérőszámok limitált jellege, valamint a válaszokban jelentkező esetleges pozitív irányú torzítás is megnehezít.

A kutatás első két kérdése a párkapcsolati minőség alakulásában mutatkozó heterogenitás mértékére és a különféle csoportok sajátos pályájára irányult. Az eredmények alapján látható volt, hogy a nők és a férfiak is két-két sajátos pályával rendelkező csoportra voltak bonthatók, így kijelenthető, hogy a párkapcsolati minőség időbeli alakulása - a hasonló típusú kutatásokkal egybehangzóan - nem egységes, a nemek átlagán túlmutat. Az elméleti részben áttekintett megközelítések többsége a párkapcsolat minőségének csökkenését feltételezte a kapcsolat kezdete után, amit a kutatás eredményei megerősítettek. A csökkenés ugyan uniform jelenségnek mutatkozott, de fontos kiemelni, hogy mértéke eltérést mutatott a különböző csoportok esetében.

Bár a csökkenést feltételező elméletek igazolást nyertek, a stabilitást, valamint a párkapcsolat kései szakaszaiban növekedést hipotetizáló megközelítések mellett is szólnak érvek. Egyfelől a női magas, valamint a férfi magas megnevezésű csoportok időben kismértékű variabilitást mutattak, ami akár stabilitásként is értelmezhető. Másfelől a férfi magas csoport kivételével az összes pálya emelkedést mutatott a párkapcsolat kései időszakában, potenciálisan igazolva az idősebb kapcsolatokban tapasztalható minőségnövekedés mellett szóló elméleteket. Összességében a pályák egészét tekintve a klasszikus U alakú trend mutatkozik a csoportok többségében, amit korábban a keresztmetszeti kutatások sajátosságának tulajdonítottak, azonban a longitudinális eredményekben is megerősítésre talál, többnyire e tanulmány eredményeihez hasonló csökkenő és növekvő időszakkal (Miller, 2000). 
Az elemzés további kérdései a párkapcsolattal való elégedettséget befolyásoló tényezőkre, valamint az azokban mutatkozó nemek közötti különbségekre vonatkoztak. Látható volt, hogy a szignifikáns változók hatása mindkét nem esetében egyirányú volt, ugyanakkor a nőknél több tényező bizonyult befolyással rendelkezőnek. A modell alapján kirajzolódó kép szerint a férfiak párkapcsolati minősége a szocializációs hatásokkal, a kapcsolat típusával és konfliktusmegoldási szokásaival függ össze, függetlenül az anyagi helyzet és a státusz bármely mutatójától, míg a nőknél a szocializációs hatások és a sajátos párkapcsolati jellemzők mellett az anyagi dimenziók és a státusz szerepe is meghatározó. E nemek közötti különbség a Bernard-féle, a nők (her) és a férfiak (his) párkapcsolatát eltérően értelmező álláspontot erősítik (Bernard,1972, idézi Corra et al., 2009; Bernard, 1976, idézi Shek, 1995).

Igazolva Amato és DeBoer (2001) elméletét és a nemzetközi kutatások eredményeit, a szülők válása láthatóan csökkentette a magasabb párkapcsolati minőséggel jellemezhető pályacsoportokba való tartozás esélyét. A háttértényezők közül sem a vallásosság, sem a korábbi válási tapasztalat nem bizonyult szignifikáns tényezőnek a párkapcsolat minőségének változásait nézve, szemben az elvált szülők egységesnek mutatkozó hatásával.

A kapcsolatspecifikus sajátosságok vizsgálata során a kapcsolat típusa, valamint a konfliktuskezelési mód a nők és a férfiak esetében is fontos tényezőnek bizonyult. Az alminta alacsony hányadát alkották azok a személyek, akik tartósan az élettársi kapcsolatot választották együttélési formaként, így feltételezhető, hogy a Liefbroer és Dourleijn (2006), valamint Bennett és munkatársai (1988) által hangsúlyozott szelekciós hatás érvényesül, mely szerint e személyek a társadalom sajátos csoportját alkotják, az átlagostól eltérő párkapcsolati folyamatokkal. A konfliktuskezelés tekintetében szintén igazolódott a Wheeler és munkatársai (2010) által feltételezett negatív hatás, a nyugodtól eltérő konfliktuskezelési módok összefüggnek a párkapcsolattal való alacsonyabb szintű elégedettséggel.

Az élveszületett gyermekszám a várakozásokhoz képest a nők esetében pozitív hatású volt, ami az egyes bemutatott elméletek szemszögéből értelmezhető. Egyfelől a magyar nők esetében a párkapcsolattal való elégedettség részét képezheti a gyermekvállalás megvalósithatósága, így a magasabb minőségű kapcsolatok együtt járnak a gyermekvállalással. Másfelől az alacsony minőségű kapcsolatokban az egyének nem vállalnak gyermeket, mert számolnak a kapcsolat felbomlásával a közeljövőben - ami egybehangzik a Becker és munkatársai (1977) által javasolt, a gyermekszámot a párkapcsolati minőség pozitív indikátoraként feltüntető gondolatmenettel. 
A háztartás anyagi helyzete esetén feltételezhető volt, hogy a nélkülözés és az ebből fakadó feszültségek és konfliktusok csökkentik a párkapcsolat minőségét. A nemzetközi empirikus kutatások eredményeivel egybehangzóan a magyar nők párkapcsolati minőségét ténylegesen csökkentette az anyagi nélkülözés, ugyanakkor a férfiaknál e hatás nem volt tetten érhető.

Végül a relatív helyzet mutatóit tekintve is szignifikáns hatás volt látható a nők esetében. A modell szerint egy nő elégedetlensége a kapcsolatával növekszik, ha ő a háztartás fő kenyérkeresője, továbbá ha egy nő relatív státusza alacsonyabb (a tradicionális nemi viszonyokra utalva), mint a párjáé, nagyobb esélIyel elégedettebb a kapcsolatával. Bár ezek az eredmények a Becker- (1981) és Parsons- (1940; 1942; 1943; 1953; 1955a; 1955b) féle elméleteket, valamint a Fáber (2019) által elgondolt hatást igazolják, fontos megjegyezni, hogy a homogám státuszú kapcsolatban élő nők hasonlóan kisebb eséllyel tartoztak a női alacsony csoportba, mint a tradicionális elrendeződéssel jellemezhetők - az alkudozási perspektíva, valamint a homofília elmélete mellett érvelve. Feltételezhető, hogy a magyar nők párkapcsolataiban mindkét hatás egyszerre érvényesül: a tradicionális kapcsolatok esetében az elkülönült nemi szerepek kölcsönös függést és kevés konfliktust hoznak, míg az egyenlőbb viszonyokkal rendelkezők párkapcsolati minősége a hasonlóság, valamint az Oppenheimer (1977) által megfogalmazott előnyök miatt lehet magasabb. Továbbá érdemes megjegyezni, hogy magyar viszonylatban a kétkeresős (egyenlőbbnek mondható) családforma hamar elterjedt, kvázi szintén tekinthető tradicionálisnak, ami megmutatkozhat a végzettségek összehasonlításában is.

A tanulmányban természetesen különböző limitációk is mutatkoztak. Az Életünk fordulópontjai kutatás egy változóval mérte a párkapcsolat minőségét, ami elfedi a kérdés komplexitását, másfelől a lekérdezések között eltelt 3-4 év miatt kevésbé részletes változások tárhatók fel. Továbbá mivel a felhasznált panelkutatás első hullámában a változó a vizsgált párkapcsolatok hossza, így maga az adatstruktúra megnehezíti az oksági kapcsolatok felállítását - kiemelten igaz ez a gyermekvállalás kérdését illetően, amelynél a legtöbb elméleti megközelítéssel és empirikus eredménnyel ellentétes hatások mutatkoztak. Harmadrészt mivel a négy hullám folyamán fennmaradt kapcsolatok szerepeltek a kutatásban, ez szelekciós hatást okozhat, ami (az esetleges konvencionalizáció mellett) alapvetően magas átlagos párkapcsolati minőséggel járhat, alacsony szórás mellett. A párkapcsolati elégedettség alakulásáról részletesebb és pontosabb képet gyakoribb ismétlődő lekérdezést alkalmazó vizsgálat adataival lehetett volna elérni, amely elegendő megfigyelési pontot biztosít az igazán alacsony minőségű, gyorsan a felbomlás felé haladó kapcsolatok vizsgálatához is. 
Zárszóként: a párkapcsolat minőségének kutatása önmagában, illetve más társadalomtudományos kérdésekkel összekapcsolva gazdag kutatási területet kínál a téma iránt érdeklődő kutatóknak. Jelen kutatás eredményei remélhetőleg ösztönzőleg hatnak a hazai társadalomtudósok számára, és további magyar eredményekkel lehetőség nyilik egy hazai diskurzus kialakítására, valamint a nemzetközi színtérbe való bekapcsolódásra. 


\section{IRODALOM}

Allport, G. W. and Ross, J. M. (1967). Personal religious orientation and prejudice. Journal of Personality and Social Psychology, 5(4), 432-443.

Amato, P. R. (1996). Explaining the intergenerational transmission of divorce. Journal of Marriage and the Family, 58(3), 628-640.

Amato, P. R. and DeBoer, D. D. (2001). The transmission of marital instability across generations: relationship skills or commitment to marriage? Journal of Marriage and Family, 63(4), 1038-1051.

Anderson, J. R., Van Ryzin, M. J. and Doherty, W. J. (2010). Developmental trajectories of marital happiness in continuously married individuals: a group-based modeling approach. Journal of Family Psychology, 24(5), 587-596.

Anthony, M. J. (1993). The relationship between marital satisfaction and religious maturity. Religious Education, 88(1), 97-108.

Aron, A., Norman, C. C., Aron, E. N. and Lewandowski, G. (2002). Shared participation in self-expanding activities: Positive effects on experienced martial quality. In P. Noller and J. A. Feeney, (Eds.), Advances in personal relationships. Understanding marriage: developments in the study of couple interaction (pp. 177-194). New York: Cambridge University Press.

Aytac, I. A. and Rankin, B. H. (2009). Economic crisis and marital problems in Turkey: testing the family stress model. Journal of Marriage and the Family, 71(3), 756-767.

Bartus T. (2015). Lemorzsolódás és súlyozás az Életünk fordulópontjai panelfelvételben. Demográfia, 58(4), 287-308.

Becker, G. S. (1981). A Treatise on the Family. Cambridge: Harvard University Press.

Becker, G. S., Landes, E. M. and Michael, R. T. (1977). An economic analysis of marital instability. Journal of Political Economy, 85(6), 1141-1187.

Bennett, N. G., Blanc, A. K. and Bloom, D. E. (1988). Commitment and the modern union: assessing the link between premarital cohabitation and subsequent marital stability. American Sociological Review, 53(1), 127-138.

Berger V. (2019). Mediatizált szerelem. A Tinder fenomenológiája. Replika, 2019(113), 63-87.

Bernard, J. S. (1972). The future of marriage. New Haven, CT: Yale University Press.

Bernard, J. S. (1976). Homosociality and female depression. Journal of Social Issues, 32(4), 213-238.

Birditt, K. S., Hope, S., Brown, E. and Orbuch, T. (2012). Developmental trajectories of marityal happiness over 16 years. Research in Human Development, 9(2), 126-144.

Bodenmann, G., Ledermann, T. and Bradbury, T. N. (2007). Stress, sex, and satisfaction in marriage. Personal Relationships, 14(4), 551-569.

Booth, A. (1977). Wife's employment and husband's stress: a replication and refutation. Journal of Marriage and the Family, 39(4), 387-398.

Booth, A. and Edwards, J. N. (1990). Transmission of marital and family quality over the generations. Journal of Divorce, 13(2), 41-58.

Booth, A. and Edwards, J. N. (1992). Starting over: why remarriages are more unstable. Journal of Family Issues, 13(2), 179-194. 
Brehm, S. S., Miller, R. S., Perlman, D. and Campbell, S. M. (2001). Intimate Relationships. New York: McGraw-Hill (third edition).

Brown, S. L. (2003). Relationship quality dynamics of cohabiting unions. Journal of Family Issues, 24(5), 583-601.

Brown, S. L. (2004). Moving from cohabitation to marriage: effects on relationship quality. Social Science Research, 33(1), 1-19.

Brown, S. L., Manning, W. D. and Payne, K. K. (2015). Relationship quality among cohabiting versus married couples. Journal of Family Issues, 38(12), 1730-1753.

Bukodi E. (2004). Ki, mikor, kivel (nem) házasodik? Párválasztás Magyarországon. Budapest: Századvég - Andorka Rudolf Társadalomtudományi Társaság.

Buunk, B. P. and Mutsaers, W. (1999). The nature of the relationship between remarried individuals and former spouses and its impact on marital satisfaction. Journal of Family Psychology, 13(2), 165-174.

Byrne, D. and Nelson, D. (1965). Attraction as a linear function of proportion of positive reinforcements. Journal of Personality and Social Psychology, 1(6), 659-663.

Caughlin, J. P. and Huston, T. L. (2006). The affective structure of marriage. In A. L. Vangelisti and D. Perlman, (Eds.), The Cambridge handbook of personal relationships (pp. 131-157). New York: Cambridge University Press.

Cherlin, A. (1977). The effect of children on marital dissolution. Demography, 14(3), 265-272.

Cherlin, A. (1978). Remarriage as an incomplete institution. American Journal of Sociology, 84(3), 634-650.

Cleek, M. G. and Pearson, T. A. (1985). Perceived causes of divorce: an analysis of interrelationships. Journal of Marriage and the Family, 47(1), 179-183.

Conger, R. D., Elder, G. H., Lorenz, F. O., Conger, K. J., Simons, R. L., Whitbeck, L. B., Huck, S. and Melby, J. N. (1990): Linking economic hardship to marital quality and instability. Journal of Marriage and Family, 52(3), 643-656.

Conger, R. D., Ge, X., Elder, G. H., Lorenz, F. O. and Simons, R. L. (1994). Economic stress, coercive family process, and developmental problems of adolescents. Child Development, 65(2), 541-561.

Corra, M., Carter, S. K., Carter, J. S. and Knox, D. (2009). Trends in marital happiness by gender and race, 1973 to 2006. Journal of Family Issues, 30(10), 1379-1404.

Delatorre, M. Z. and Wagner, A. (2019). How do couples disagree? An analysis of conflict resolution profiles and the quality of romantic relationships. Revista Colombiana de Psicología, 28(2), 91-108.

Dyer, E. D. (1963). Parenthood as a crisis: a re-study. Journal of Marriage and Family, 25(2), 196-202.

Dudley, M. G. and Kosinski, F. A. (1990). Religiosity and marital satisfaction: a research note. Review of Religious Research, 32(1), 78-86.

Edmonds, V. H. (1967). Marital conventionalization: definition and measurement. Journal of Marriage and the Family, 29(4), 681-688.

Erát D. (2018). A vallás és a párválasztás. In Kiss G., (szerk.), Fiatal Kutatók és Doktoranduszok VIII. Nemzetközi Teológuskonferenciájának tanulmánykötete (58-66. o.). Budapest: Doktoranduszok Országos Szövetsége - Falk1 Edutus Ház Rendezvényközpont. 
Erát D. (2019). Összefüggések a párkapcsolat szerkezete és felbomlása között a nemzetközi szakirodalom tükrében. Szociológiai Szemle, 29(3), 23-39.

Esteve, A., Román, J. G. and Permanyer, I. (2012). The gender-gap reversal in education and its effect on union formation: The end of hypergamy? Population and Development Review, 38(3), 535-546.

Fáber Á. (2019). Az autotelikus párkapcsolat és a gyerekvállalás mint „metaprojekt”. Replika, 2019(110), 95-137.

Földházi E. (2008): Az első házasság felbomlása - eseménytörténeti elemzés. Demográfia, 57(1), 79-111.

Foran, H. M., Hahlweg, K., Kliem, S. and O'Leary, K. D. (2013). Longitudinal patterns of relationship adjustment among German parents. Journal of Family Psychology, 27(5), 838-843.

Glenn, N. D. and Weaver, C. N. (1977). The marital happiness of remarried divorced persons. Journal of Marriage and Family, 39(2), 331-337.

Glenn, N. D. and McLanahan, S. (1982). Children and marital happiness: a further specification of the relationship. Journal of Marriage and the Family, 44(1), 63-72.

Gödri I. (2001). A házassági kapcsolatok minősége és stabilitása (KSH Népességtudományi Kutatóintézet Kutatási Jelentések 66). Budapest: KSH Népességtudományi Kutatóintézet.

Gottman, J. M. (1993). A theory of marital dissolution and stability. Journal of Family Psychology, 7(1), 57-75.

Grow, A. and Van Bavel, J. (2015). Assortative mating and the reversal of gender inequality in education in Europe: An agent-based model. Plos One, 10(6), 1-24.

Hardie, J. H. and Lucas, A. (2010). Economic factors and relationship quality among young couples: comparing cohabitation and marriage. Journal of Marriage and Family, 72(5), 1141-1154.

Hicks, M. W. and Platt, M. (1970). Marital happiness and stability: a review of the research in the sixties. Journal of Marriage and the Family, 32(4), 553-574.

Hobart, C. (1991). Conflict in remarriages. Journal of Divorce \& Remarriage, 15(3-4), 69-86. Huston, T. L. and Houts, R. M. (1998). The psychological infrastructure of courtship and marriage: the role of personality and compatibility in romantic relationships. In T. N. Bradbury, (Eds.), The Developmental Course of Marital Dysfunction (pp. 114-152). New York: Cambridge University Press.

Huston, T. L., Caughlin, J. P., Houts, R. M., Smith, S. E. and George, L. J. (2001a). The connubial crucible: newlywed years as predictors of marital delight, distress, and divorce. Journal of Personality and Social Psychology, 80(2), 237-252.

Huston, T. L., Niehuis, S. and Smith, S. E. (2001b). The early marital roots of conjugal distress and divorce. Current Directions in Psychological Science, 10(4), 116-119.

Jackson, J. B., Miller, R. B., Oka, M. and Henry, R. G. (2014). Gender differences in marital satisfaction: a meta-analysis. Journal of Marriage and Family, 76(1), 105-129.

Johnson, D. R. (1995). Assessing marital quality in longitudinal and life course studies. In J. C. Conoley and E. B. Werth, (Eds.), Family Assessment. Lincoln: Buros Institute of Mental Measurements, University of Nebraska-Lincoln.

Johnson, D. R., White, L. K., Edwards, J. N. and Booth, A. (1986). Dimensions of marital quality. Journal of Family Issues, 7(1), 31-49. 
Jones, B. L. and Nagin, D. S. (2013). A note on a Stata plugin for estimating group-based trajectory models. Sociological Methods \& Research, 42(4), 608-613.

Karney, B. R. and Bradbury, T. N. (1997). Neuroticism, marital interaction, and the trajectory of marital satisfaction. Journal of Personality and Social Psychology, 72(5), 1075-1092.

Kelley, H. H., LeBaron, A. B. and Hill, E. (2018). Financial stress and marital quality: the moderating influence of couple communication. Journal of Financial Therapy, 9(2), 18-36.

Kurdek, L. A. (1999). The nature and predictors of the trajectory of change in marital quality for husbands and wives over the first 10 years of marriage. Development Psychology, 35(5), 1283-1296.

LeMasters, E. E. (1957). Parenthood as Crisis. Marriage and Family Living, 19(4), 352-355.

Levenson, R. W., Carstensen, L. L. and Gottman, J. M. (1993). Long-term marriage: age, gender, and satisfaction. Psychology and Aging, 8(2), 301-313.

Levinger, G. (1966). Sources of marital dissatisfaction among applicants for divorce. American Journal of Orthopsychiatry, 36(5), 803-807.

Li, X., Cao, H., Lan, J., Ju, X., Zheng, Y., Chen, Y., Zhou, N. and Fang, X. (2017). The association between transition pattern of marital conflict resolution styles and marital quality trajectory during the early years of Chinese marriage. Journal of Social and Personal Relationships, 36(1), 153-186.

Liefbroer, A. C. and Dourleijn, E. (2006). Unmarried cohabitation and union stability: testing the role of diffusion using data from 16 European countries. Demography, 43(2), 203-221.

Lindahl, K., Clements, M. and Markman, H. (1998). The development of marriage: A 9-year perspective. In T. Bradbury, (Eds.), The developmental course of marital dysfunction (pp. 205-236). New York: Cambridge University Press.

Liu, G. (2002). How premarital children and childbearing in current marriage influence divorce of Swedish women in their first marriages. Demographic Research, 7(10), 389-406.

Lorber, M. F., Erlanger, A. C. E., Heyman, R. E. and O'Leary K. D. (2015). The honeymoon effect: does it exist and can it be predicted? Prevention Science, 16(4), 550-559.

Lupri, E. and Frideres, J. (1981). The Quality of Marriage and the Passage of Time: Marital Satisfaction over the Family Life Cycle. The Canadian Journal of Sociology / Cahiers Canadiens de Sociologie, 6(3), 283-305.

Makay Zs. (2016). Kikerülés követéses vizsgálatból elhalálozás, válaszmegtagadás és egyéb okok miatt: panelkopás az „Életünk fordulópontjai” adatfelvételben. Szociológiai Szem/e, 26(3), 99-121.

Miller, R. B. (2000). Misconceptions about the U-shaped curve of marital satisfaction over the life course. Family Science Review, 13(1-2), 60-73.

Monostori J. (2019). Egyszülős családok és politikák Magyarországon és Európában. Demográfia, 62(1), 5-41.

Murinkó L. és Spéder Zs. (szerk.) (2016). Felhasználói kézikönyv az Életünk fordulópontjai panelkutatás 1-4. hullámához (KSH Népességtudományi Kutatóintézet Kutatási Jelentések 97). Budapest: KSH Népességtudományi Kutatóintézet.

Myers, S. M. (2006). Religious homogamy and marital quality: historical and generational patterns, 1980-1997. Journal of Marriage and Family, 68(2), 292-304. 
Nagin, D. S. (2005). Group-based modeling of development over the life course. Cambridge: Harvard University Press.

Nagin, D. S. (2014). Group-based trajectory modelling: an overview. Annals of Nutrition \& Metabolism, 65(2-3), 205-210.

Niehuis, S., Reifman, A., Feng, D. and Huston, T. L. (2015). Courtship progression rate and declines in expressed affection early in marriage: a test of the disillusionment model. Journal of Family Issues, 37(8), 1074-1100.

Nock, S. L. (1995). A comparison of marriages and cohabiting relationships. Journal of Family Issues, 16(1), 53-76.

Oppenheimer, V. K. (1977). The sociology of women's economic role in the family. American Sociological Review, 42(3), 387-406.

Greeff, P. and De Bruyne, T. (2000). Conflict management style and marital satisfaction. Journal of Sex \& Marital Therapy, 26(4), 321-334.

Parsons, T. (1940): An analytical approach to the theory of social stratification. In T. Parsons, (Ed.), Essays in sociological theory (pp. 69-89). Glencoe: Free Press.

Parsons, T. (1942): Age and sex in the social structure of the United States. In T. Parsons, (Ed.), Essays in sociological theory (pp. 89-104). Glencoe: Free Press.

Parsons, T. (1943): The kinship system of the contemporary United States. In T. Parsons, (Ed.), Essays in sociological theory (pp. 177-197). Glencoe: Free Press.

Parsons, T. (1953): A revised analytical approach to the theory of social stratification. In T. Parsons, (Ed.), Essays in sociological theory (pp. 386-440). Glencoe: Free Press.

Parsons, T. (1955a). The American family: its relations to personality and to the social structure. In T. Parsons and R. F. Bales, (Eds.), Family, socialization and interaction process (pp. 35-133). Glencoe: Free Press.

Parsons, T. (1955b). Family structure and the socialization of the child. In T. Parsons and R. F. Bales, (Eds.), Family, socialization and interaction process (pp. 3-35). Glencoe: Free Press.

Pearlin, L. I. (1975). Status inequality and stress in marriage. American Sociological Review, 40(3), 344-357.

Pilinszki A. (2013). „Az ágy közös, a párna nem.” A párkapcsolati instabilitás nemi sajátosságai. Socio.hu, 3(4), 41-53.

Pollak, R. A. (2005). Bargaining power in marriage: earnings, wage rates and household production (NBER Working Papers 11239) Cambridge: National Bureau of Economic Research.

Proulx, C. M., Helms, H. M. and Buehler, C. (2007). Martial quality and personal wellbeing: a meta-analysis. Journal of Marriage and Family, 69(3), 576-593.

Ramu, G. N. (1984). Family background and perceived marital happiness: a comparison of voluntary childless couples and parents. The Canadian Journal of Sociology / Cahiers Canadiens de Sociologie, 9(1), 47-67.

Rhyne, D. (1981). Bases of marital satisfaction among men and women. Journal of Marriage and the Family, 43(4), 941-955.

Rijken, A. J. and Thomson, E. (2011). Partners' relationship quality and childbearing. Social Science Research, 40(2), 485-494.

Robles, T. F. (2014). Martial quality and health. Current Directions in Psychological Science, 23(6), 427-432. 
Rogers, E. M. and Bhowmik, D. P. (1970). Homophily-heterophily: relational concepts for communication research. Public Opinion Quarterly, 34(4), 523-538.

Rohr A. (2017). Vélemények a házasságról és az élettársi kapcsolatról Magyarországon a rendszerváltást követő 25 évben. Demográfia, 60(2-3), 173-195.

Rohr, A. (2018). Does the survey mode influence the results about partnership quality? (Hungarian Demographic Research Institute Research Highlights 32). Budapest: KSH Népességtudományi Kutatóintézet.

Rollins, B. C. and Cannon, K. L. (1974). Marital satisfaction over the family life cycle: a reevaluation. Journal of Marriage and the Family, 36(2), 271-282.

Rövid I. (2018). Pillanatfelvétel a szinglikről. A szinglik általános és területi jellemzői a népszámlálási adatok alapján. Területi Statisztika, 58(3), 302-318.

Safilios-Rothschild, C. (1975). Family and stratification: some macrosociological observations and hypotheses. Journal of Marriage and the Family, 37(4), 855-860.

Schaefer, D. R. (2012). Homophily through non reciprocity: results of an experiment. Social Forces, 90(4), 1271-1295.

Shehan, C. L., Bock, E. W. and Lee, G. R. (1990). Religious heterogamy, religiosity and marital happiness: the case of Catholics. Journal of Marriage and the Family, 52(1), 73-79.

Shek, D. T. L. (1995). Gender differences in marital quality and well-being in Chinese married adults. Sex Roles, 32(11-12), 699-715.

Skinner, K. B., Bahr, S. J., Crane, D. R. and Call, V. R. A. (2002). Cohabitation, marriage, and remarriage. Journal of Family Issues, 23(1), 74-90.

Spanier, G. B. (1979). The measurement of marital quality. Journal of Sex \& Marital Therapy, 5(3), 288-300.

Spéder Zs. (2005). Az élettársi kapcsolat térhódítása Magyarországon és néhány szempont a demográfiai átalakulás értelmezéséhez. Demográfia, 48(3-4), 187-217.

Sullivan, K. T. (2001). Understanding the relationship between religiosity and marriage: An investigation of the immediate and longitudinal effects of religiosity on newlywed couples. Journal of Family Psychology, 15(4), 610-626.

Vaillant, C. O. and Vaillant, G. E. (1993). Is the U-curve of martial statisfaction an illusion? A 40-year study of marriage. Journal of Marriage and Family, 55(1), 230-239.

VanLaningham, J., Johnson, D. R., and Amato, P. (2001). Marital happiness, marital duration, and the U-shaped curve: evidence from a five-wave panel study. Social Forces, 79(4), 1313-1341.

Vannoy, D. and Cubbins, L. A. (2001). Relative socioeconomic status of spouses, gender attitudes, and attributes, and marital quality experienced by couples in metropolitan Moscow. Journal of Comparative Family Studies, 32(2), 195-217.

Vannoy, D. and Philliber, W. W. (1992). Wife's Employment and quality of marriage. Journal of Marriage and the Family, 54(2), 387-398.

Veevers, J. E. (1980). Childless by choice. Toronto: Butterworth.

Vemer, E., Coleman, M., Ganong, L. and Cooper, H. (1989). Marital satisfaction in remarriage: a meta-analysis. Journal of Marriage and the Family, 51(3), 713-725.

Waller, W. (1938). The family: a dynamic interpretation. New York: Cordon. 
Wheeler, L. A., Updegraff, K. A. and Thayer, S. M. (2010). Conflict resolution in Mexican-origin couples: culture, gender, and marital quality. Journal of Marriage and Family, 72(4), 991-1005.

White, L. K., Booth, A. and Edwards, J. N. (1986). Children and marital happiness. Journal of Family Issues, 7(2), 131-147.

Whitton, S., Rhoades, G. K., Stanley, S. M. and Markman, H. J. (2008): Effects of parental divorce on marital commitment and confidence. Journal of Family Psychology, 22(5), 789-793.

Zhang, H. (2015). Wives' relative income and marital quality in urban China: gender role attitudes as a moderator. Journal of Comparative Family Studies, 46(2), 203-220. 


\section{MELLÉKLET}

M1. táblázat: A végső alminta elemszámához vezető lépések

\section{A megfigyelések szürésének okai}

Mind a négy hullámban szereplő személyek

Az első hullámban a partnerükkel élők

A második hullámig együtt éltek

A harmadik hullámig együtt éltek

A negyedik, utolsó lekérdezésig együtt éltek

Inkonzisztens partner- és együttélés adatok

Egynél több esetben hiányzó párkapcsolattal való elégedettségérték
Elemszám változása

8103

5511

4416

3880

3404

3384

3268

Forrás: Életünk fordulópontjai panelkutatás longitudinális adatbázisa (2001-2013).

Megjegyzés: mivel az alkalmazott módszernek minimum három megfigyelési időpontból származó adatra van szüksége, így az ennél több hiányzó elégedettségi véleménnyel rendelkező személyek kikerültek az almintából.

M2. táblázat: A modellek illeszkedési mutatóinak összehasonlitása különböző csoportszámú és pályájú modellek esetén (nők)

\begin{tabular}{ccccccccc}
$\begin{array}{c}\text { Csoportok } \\
\text { száma }\end{array}$ & Modell & $\mathrm{LL}$ & $\mathrm{AIC}$ & $\mathrm{BIC}(7277)$ & $\mathrm{BIC}(1822)$ & Becsült arányok & $\begin{array}{c}\text { Kiválasz- } \\
\text { tott modell }\end{array}$ \\
\hline 1 & 1 & $-12343,08$ & $-12346,08$ & $-12356,42$ & $-12354,35$ & 1 & - & \\
1 & 2 & $-12291,35$ & $-12295,35$ & $-12309,14$ & $-12306,37$ & 1 & - & \\
1 & 3 & $-12291,22$ & $-12296,22$ & $-12313,45$ & $-12309,99$ & 1 & - & \\
2 & 1,1 & $-11725,90$ & $-11731,90$ & $-11752,58$ & $-11748,42$ & 0,44 & 0,56 & \\
2 & 1,2 & $-11713,16$ & $-11720,16$ & $-11744,28$ & $-11739,43$ & 0,42 & 0,58 & \\
2 & 1,3 & $-11712,80$ & $-11720,80$ & $-11748,37$ & $-11742,83$ & 0,42 & 0,58 & \\
2 & 2,1 & $-11711,90$ & $-11718,90$ & $-11743,03$ & $-11738,18$ & 0,47 & 0,53 & \\
2 & 2,2 & $-11696,71$ & $-11704,71$ & $-11732,28$ & $-11726,74$ & 0,44 & 0,56 & $x$ \\
2 & 2,3 & $-11696,60$ & $-11705,60$ & $-11736,62$ & $-11730,39$ & 0,44 & 0,56 & \\
2 & 3,1 & $-11711,66$ & $-11719,66$ & $-11747,23$ & $-11741,69$ & 0,47 & 0,53 & \\
2 & 3,2 & $-11696,19$ & $-11705,19$ & $-11736,21$ & $-11729,97$ & 0,44 & 0,56 & \\
2 & 3,3 & $-11696,09$ & $-11706,09$ & $-11740,55$ & $-11733,63$ & 0,44 & 0,56 &
\end{tabular}

Forrás: Életünk fordulópontjai panelkutatás Iongitudinális adatbázisa (2001-2013)

Megjegyzés: $\mathrm{BIC}=$ bayesian information criterion; $\mathrm{AIC}=$ akaike information criterion; $\mathrm{LL}=$ log-likelihood. A modell esetében az „1” lineáris, a „2” másodfokú, a „,3” pedig harmadfokú görbével rendelkező csoportot jelöl. A modellválasztás során a három csoporttal rendelkező modellek kikerültek a harmadik csoport konzisztensen alacsony aránya $(<0,08)$ miatt. 
M3. táblázat: A modellek illeszkedési mutatóinak összehasonlitása különböző csoportszámú és pályájú modellek esetén (férfiak

\begin{tabular}{ccccccccc}
$\begin{array}{c}\text { Csoportok } \\
\text { száma }\end{array}$ & Modell & $L L$ & AIC & BIC(5777) & BIC(1446) & Becsült arányok & $\begin{array}{c}\text { Kiválasz- } \\
\text { tott modell }\end{array}$ \\
\hline 1 & 1 & $-8261,62$ & $-8264,62$ & $-8274,62$ & $-8272,54$ & 1 & - & \\
1 & 2 & $-8242,51$ & $-8246,51$ & $-8259,84$ & $-8257,07$ & 1 & - & \\
1 & 3 & $-8241,29$ & $-8246,29$ & $-8262,94$ & $-8259,48$ & 1 & - & \\
2 & 1,1 & $-7962,43$ & $-7968,43$ & $-7988,41$ & $-7984,26$ & 0,46 & 0,54 & \\
2 & 1,2 & $-7958,17$ & $-7965,17$ & $-7988,49$ & $-7983,64$ & 0,45 & 0,55 & \\
2 & 1,3 & $-7954,20$ & $-7962,20$ & $-7988,85$ & $-7983,31$ & 0,45 & 0,55 & \\
2 & 2,1 & $-7956,24$ & $-7963,24$ & $-7986,55$ & $-7981,70$ & 0,49 & 0,51 & \\
2 & 2,2 & $-7951,70$ & $-7959,70$ & $-7986,34$ & $-7980,80$ & 0,47 & 0,53 & \\
2 & 2,3 & $-7948,34$ & $-7957,34$ & $-7987,32$ & $-7981,09$ & 0,47 & 0,53 & $x$ \\
2 & 3,1 & $-7956,23$ & $-7964,23$ & $-7990,87$ & $-7985,33$ & 0,49 & 0,51 & \\
2 & 3,2 & $-7951,69$ & $-7960,69$ & $-7990,67$ & $-7984,44$ & 0,47 & 0,53 & \\
2 & 3,3 & $-7948,27$ & $-7958,27$ & $-7991,58$ & $-7984,66$ & 0,47 & 0,53 &
\end{tabular}

Forrás: Életünk fordulópontjai panelkutatás longitudinális adatbázisa (2001-2013)

Megjegyzés: $\mathrm{BIC}=$ bayesian information criterion; $\mathrm{AIC}=$ akaike information criterion; $\mathrm{LL}=$ log-likelihood.

A modell esetében az „1" lineáris, a „2” másodfokú, a „3” pedig harmadfokú görbével rendelkező csoportot jelöl. A modellválasztás során a három csoporttal rendelkező modellek kikerültek a harmadik csoport konzisztensen alacsony aránya $(<0,08)$ miatt. 


\section{THE DEVELOPMENT OF RELATIONSHIP SATISFACTION OVER TIME: POSSIBLE TRAJECTORIES AND DETERMINANTS}

\section{ABSTRACT}

The present paper examines the relationship satisfaction trajectories and their possible determinants in the case of Hungarian women and men. A group-based trajectory analysis was conducted, using data from four waves (2001/20022012/2013) of the Hungarian Generations and Gender Survey, called Életünk fordulópontjai. The group-based approach identifies distinct trajectory groups of relationship quality, therefore uncovering the underlying heterogeneity behind women's and men's mean satisfaction change over time. A high (57\%) and low (43\%) satisfaction group were discovered amongst women, while men had a high (54\%) and an average (46\%) group, but a general decline in the first years of the relationship was observed in all four distinct trajectories.

For women, a lower level of relationship satisfaction was linked with parental divorce, living in a cohabitation instead of being married, non-peaceful conflict resolution methods, economic hardships and being the only breadwinner, while children and a traditional or homogamous relative status compared to their partners was found to increase satisfaction. Men had similar effects regarding parental divorce, relationship type and conflict resolution, but economic and status related variables were not significant. 